\title{
6
}

\section{La desnaturalización de las cooperativas}

Estudio de los instrumentos financieros de carácter societario y del modelo de expansión «no-cooperativo» de Eroski S. Coop.

D. Unai del Burgo

Premio AIDC 2002

«Para las sociedades cooperativas, en un mundo cada vez más competitivo y riguroso en las reglas del mercado, la competitividad se ha convertido en un valor consustancial a su naturaleza cooperativa...»

Exposición de Motivos de la Ley 27/1999, de 16 de julio, de Cooperativas

«Evidentemente, ni los trabajadores ni los consumidores serán socios en tales proyectos...»

Constan Dacosta, Presidente-Director del Grupo Eroski

«¿Dejaríamos entrar a los zorros en los gallineros? Seguramente, no. Porque sabemos que, tarde o temprano, los zorros conseguirán aflojar las ligaduras con las que tratemos de detenerlos»

\section{Alicia Kaplan de Drimer}

«Ser realistas y pragmáticos no quiere decir renunciar a los ideales, que no deben ser confundidos con quimeras y bellos sueños, sino aceptarlos como objetivos a realizar»

Jose María Arizmendiarrieta 


\section{Introducción}

«Un cooperativismo sin aptitud estructutal para atraer y asimilar los capitales al nivel de las exigencias de la productividad industrial es una solución transitoria, una fórmula caduca». Tal y como afirmaba el Padre Arizmendiarrieta, las necesidades de financiación son intrínsecas a la empresa cooperativa: admitidas las condiciones económicas impuestas por el actual mercado concurrencial, este estudio trata de determinar la relación entre ciertos mecanismos facilitadores de captación de capital externo a la sociedad cooperativa y la progresiva «Desnaturalización» de la misma.

En primer lugar, se analizan los valores y principios que dotan al Cooperativismo Vasco de una posición privilegiada dentro de la teorización ideológica cooperativa global. Dichos valores inspirarán, a continuación, la crítica, esperemos constructiva, de los diferentes mecanismos financieros utilizados por las cooperativas para acceder al mercado de capitales.

En segundo lugar, son objeto de estudio los instrumentos financieros de carácter societario (es decir, aquellos que confieren derechos societarios al mero aportante de capital), facilitadores del proceso de «Desnaturalización» de las sociedades cooperativas: partiendo de la posición crítica de la Doctora Alicia Kaplan de Drimer, se abordarán las líneas legislativas vasco y estatales en relación a este tema, tratando paralelamente de fundamentar una opinión realista frente a estas figuras de marcado carácter heterodoxo. En el mismo orden de cosas, este estudio también versará sobre las razones de diversa índole que obligan a las cooperativas a transformarse en sociedades de capitales: el peligro de «Desmutualización».

En tercer lugar, se pretende exponer las circunstancias financieras que obligaron a Eroski S. Coop a desarrollar su modelo de expansión «no-cooperativo» llevado a cabo mediante sociedades de capitales, recalcando su esfuerzo por evitar las «injerencias capitalistas» en el seno de su organización. No obstante, comprobaremos cómo, al igual que la utilización de figuras societarias de captación de capital, el proceso de expansión ajeno al cooperativismo "desnaturaliza» la proyección exterior de la identidad cooperativa. Con respecto al caso del Grupo Eroski, y con el propósito de valorar adecuadamente su grado de «desnaturalización», analizaremos profundamente el intento de «cooperativización» realizado por la sociedad civil particular denominada Gespa. 
En conclusión, este trabajo trata de ofrecer una valoración crítica, a la vez que realista, de estos mecanismos «desnaturalizadores» de la Identidad Cooperativa.

\section{Valores de la cultura económica del cooperativismo vasco. Aproximación a la experiencia cooperativa de Mondragón}

El Cooperativismo Vasco es un movimiento con valores propios pero que, indudablemente, ha tenido la suerte de enriquecerse de diferentes fuentes, algunas doctrinales, otras extraídas de la práctica cooperativa. Se ha apoyado en los valores y principios Rochdelianos de la Alianza Cooperativa Internacional [International Co-operative Alliance $(\mathrm{ACl})$ ], pero ha recorrido un camino paralelo a ella, constituyéndose como un marco de valores propios ${ }^{1}$, con especificidades propias:

- Goza de un mayor realismo y aplica un menor dogmatismo o formalismo a su formulación ideológica y teórica: en el País Vasco el cooperativismo no deja de ser una Experiencia.

- Toma como valores básicos el Trabajo y la Solidaridad: prueba fehaciente de ello es el papel principal que desempeñan las cooperativas de trabajo asociado en el entorno cooperativo vasCO.

-El pensamiento de Jose María Arizmendiarrieta supuso, desde un principio, el centro de inspiración de un movimiento que él mismo caracterizó.

Tradicionalmente, la experiencia cooperativa de Mondragón ha desarrollado sus propios postulados, inspirados por el padre Arizmendiarrieta, mientras que las Federaciones de Cooperativas y su Confederación (aquella que aglutina las diferentes federaciones de los diferentes tipos de cooperativas) se han visto más condicionadas por los valores y principios promulgados por la $\mathrm{ACl}$. Pero el fenómeno de la Economía Social en Euskadi no se limita únicamente al cooperativismo: las Sociedades Laborales son formas jurídicas propias de la legislación española (Ley 471.997 de 24 de marzo, de Sociedades Laborales), desconociéndose otros ejemplos en el derecho comparado. En ellas la mayoría del capital social se encuentra en manos de los traba-

1 Zelaia UlibarRI, Adrián (1996), «Valores del cooperativismmo vasco en Arizmendiarrieta», Anuario de Estudios Cooperativos, Universidad de Deusto, Bilbao. 
jadores indefinidos a tiempo completo o parcial. En el País Vasco poseen su propia federación, ASLE (Asociación de Sociedades Laborales de Euskadi) muy cercana a la cultura sindical².

\subsection{La Alianza Cooperativa Internacional y la Declaración sobre la Identidad Cooperativa. Evolución}

La $\mathrm{ACl}$ posee una indudable influencia en la concreción de los valores del cooperativismo vasco y su posterior aplicación en la experiencia práctica de las cooperativas que forman nuestro entorno.

A escala mundial, desde que se creara en 1885, la Alianza Cooperativa Internacional es la encargada de concretar en última instancia el significado y valor de ser cooperativa hoy. En el artículo 8 de sus estatutos, establece que, para que una organización sea aceptada como miembro de la Alianza debe necesariamente realizar su actividad respetando los valores y principios cooperativos. De esta manera consta este precepto desde que en 1937, los líderes de la ACI propusieran al Congreso Cooperativo incorporar en su reglamento dicha disposición.

Según A. Bonner ${ }^{3}$, «el movimiento cooperativo tiende al logro de fines que son en sí mismos estados de perfección inalcanzables, pero que operan como un verdadero norte para su actividad (valores). Existen pautas o guías de acción (principios cooperativos) que aseguran a través de su observancia estar orientados hacia los fines perseguidos (valores)».

Anteriormente a 1995, año en que la $\mathrm{ACl}$ presentó la actual Declaración sobre la Identidad Cooperativa, la Alianza realizó dos listados oficiales de principios cooperativos basados en las experiencias prácticas llevadas a cabo por la Sociedad de los Probos Pioneros de Rochdale. En los estatutos de esta sociedad, se fijaron una serie de normas que a posteriori determinaron la esencia del cooperativismo actual. La primera declaración fue confeccionada en su $15 .{ }^{\circ}$ Congreso de París de 1937. Pero dicha esencia cooperativa sufre la necesidad de

2 ZelalA UlíbarRI, Adrián (1997), Kooperatibak Euskal Herrian, Udako Euskal Unibertsitatea, Bilbao; SALABERRía AMESTI, Javier, "Las Cooperativas Vascas Presente y Futuro», I Jornadas Universitarias de Economía Social, Facultad de Ciencias Económicas y Empresariales de la UPV/EHU (Sarriko), 11 de marzo de 2002, Bilbao. Inédito.

3 «Ideale and Principles of Cooperation», Lessons outlines, Co-operative Union, Manchester, lesson no. II. 
adaptarse, de actualizarse, formulándose en el $23 .^{\circ}$ Congreso de la $\mathrm{ACl}$, celebrado en Viena en 1966, el segundo listado de criterios o pautas cooperativas.

Al igual que los pioneros de Rochdale, quienes realizaron tres modificaciones estatutarias durante los diez primeros años de vida de su experiencia cooperativa, la $\mathrm{ACl}$ se planteó readaptar una vez más el diseño de la identidad cooperativa: en su $27 .{ }^{\circ}$ Congreso celebrado en Moscú, empezó a vislumbrarse el primer intento de cambio, materializado en el informe de Alex L. Laidlaw sobre el papel a desempeñar por el cooperativismo en el año 2000. En la década de los setenta, la economía de mercado comenzaba su actual expansión, alterando el marco en que, durante decenios, las cooperativas habían realizado sus actividades. Este suceso da inicio a un nuevo proceso de revisión de la esencia cooperativa: surgen diferentes propuestas e informes sobre las pautas a seguir por las cooperativas en un futuro ya muy próximo y lleno de incertidumbres. Destacamos el informe presentado por Sven Ake Böök ${ }^{4}$ en el 30. ${ }^{\circ}$ Congreso celebrado en Tokio en 1992 y el propuesto por lan McPherson ${ }^{5}$.

Este proceso de readaptación a los nuevos tiempos culmina con el 31. ${ }^{\circ}$ Congreso de la ACl, celebrado en Manchester, en 1995, en el que además de fijarse por vez primera una definición específica de cooperativa ("Una cooperativa es una asociación autónoma de personas que se han unido de forma voluntaria para satisfacer sus necesidades y aspiraciones económicas, sociales y culturales en común mediante una empresa de propiedad conjunta y de gestión democrática») y un listado de los valores («Las cooperativas están basadas en los valores de la autoayuda, la autorresponsabilidad, la democracia, la igualdad, la equidad y la solidaridad. En la tradicción de sus fundadores, los socios cooperativos hacen suyos los valores éticos de la honestidad, la transparencia, la responsabilidad y la vocación social») se aumentan a siete los principios rectores de la actuación cooperativa: adhesión voluntaria; gestión democrática por parte de los socios; participación económica de los socios; autonomía e independencia; educación, for-

4 Böök, S.A., "Valores cooperativos para un mundo cambiante», Informe para el XXX Congreso de la ACl, Tokio, octubre de 1992. Distingue tres tipos de valores básicos ideas (igualdad y democracia), Eticas y Principios Básicos (democracia y participación del socio).

5 MCPherson, I., «Reformulación de los Principios Cooperativos». Noticias. Asociación Latinoamericana de Centros de Educación Cooperativa (ALCECOOP). 
mación e información; cooperación entre cooperativas e interés por la comunidad.

El cuarto principio no aparecía expresamente citado en la formulación de 1966, por lo que la ACI vuelve de alguna manera a la posición que promulgaba en 1937, en la que garantizaba el principio de neutralidad política y religiosa ${ }^{6}$. Una de las causas de tomar nuevamente en consideración este importante aspecto es la preocupación por mantener el control democrático y la autonomía de las cooperativas: dadas las dificultades de financiación sufridas por este tipo de empresas, incapaces de abastecerse de suficientes recursos propios para realizar su objeto social, las cooperativas se ven obligadas a financiarse mediante capitales externos (inversores no vinculados con la finalidad de la cooperativa y que únicamente desean obtener rentabilidad de sus aportaciones al capital): actualmente, muchas entidades cooperativas otorgan concesiones de naturaleza políticas y económicas (derechos a terceros no-socios concedidos por las diferentes legislaciones cooperativas), afectando a su autonomía e independencia, conduciéndolas a corto o medio plazo a procesos como los de «Desnaturalización»o «Desmutualización» que más adelante trataremos de explicar?

\subsection{El Pensamiento de Jose María Arizmendiarrieta y su influencia en el Cooperativismo vasco ${ }^{8}$. Trabajo y unión}

Jose María Arizmendiarrieta Madariaga nació en Markina (Bizkaia), un 14 de abril del año 1915, en el caserío Iturbe del barrio de Barinaga. Sacerdote, creador de cooperativas y pensador personalista, fue el artífice principal, el inspirador de lo que hoy es Mondragón Corporación Cooperativa (MCC), de la cual Eroski es parte integrante en su Sección de Distribución.

Desarrolló un peculiar pensamiento, que no «ideología», en el que el fin primordial no era la creación de un sistema político cerrado, sino la maduración de una concepción de comunidad en la cual la

6 Kaplan de Drimer, Alicia (1995), «El XXXI Congreso de la Alianza Cooperativa Internacional y la Nueva Formación de los principios Cooperativos», Anuario de Estudios Cooperativos, Universisdad de Deusto, Bilbao.

7 KaPLAN DE DRIMER, Alicia (1998), «¿Dejaríamos entrar a los zorros en los gallineros?», Anuario de Estudios Cooperativos, Universidad de Deusto, Bilbao.

8 Zelaia Ulíbarri, Adrián (1996), op. cit. 
Etica, el Humanismo y la Empresa confluían en torno a un fin común: la búsqueda del hombre cooperativo, preocupado tanto por su desarrollo personal (dignidad, formación, capacitación, superación...), como por el desarrollo comunitario (igualdad y solidaridad). En definitiva, como cita Joxe Azurmendi en su libro «El Hombre Cooperativo» (Azatza, Otalora, 1992), crea «un modelo que realiza el orden personalista, dentro y contra el capitalismo, sin esperar a su liquidación histórica».

Arizmendiarrieta se inspiró en diversas fuentes, fuentes muy dispares entre sí: seguidor de la Doctrina Social de la Iglesia, acercamiento a pensadores personalistas como Maritain y Mounier, admiración por los clásicos del cooperativismo, influencias del Socialismo Utópico, teorías liberales, Federalismo Anarquista y la tradición social vasca (tradición social-cristiana de los «sacerdotes propagandistas», Ugetistas y activistas de la clase trabajadora relacionados con el «Socialismo eibarrés»).

Junto al Humanismo Cristiano, la influencia ideológica más directa en el origen del pensamiento de Arizmendiarrieta y, por consiguiente, en el posterior desarrollo de la Experiencia de Mondragón es el Sindicalismo de ELA de preguerra, sindicato estrechamente ligado a la actividad social cristiana. Este sindicato ideó un complejo entramado en el que el cooperativismo se constituía como clave principal para el desarrollo económico y social del País Vasco (Congreso de Vitoria de 1933). En efecto, en torno a los años treinta, uno de los mayores desarrollos doctrinales en el País Vasco en materia cooperativa fue realizado por la teorización de los ideólogos del sindicato ELA 9 .

El pilar central del Pensamiento de Arizmendiarrieta, en este aspecto claramente influido por el personalismo comunitario de Mounier, lo constituyen conjuntamente la persona y la comunidad: el trabajo toma un valor excepcional en su modelo vital y lo utiliza como un instrumento transformador de la esencia misma de la persona y de la sociedad donde ésta vive. En este proceso de desarrollo comunitario, la FORMACIÓN adquiere una importancia clave.

La economía se nos muestra totalmente ideologizada, ligada de forma profunda a la ética (empresa y ética son conceptos inseparables):

9 SABerRI AMEStI, Javier (2002) op. cit.; OlABARRI, Ignacio, «Tradiciones Cooperativas Vascas», Euskal Herria, Historia y Sociedad, Ed. Caja Laboral. 
el ser humano no es un instrumento, sino el fundamento y el fin último de la acción social materializada en la propia empresa cooperativa, donde el trabajo se enmarca en un contexto de SOLIDARIDAD. TRABAJO y UNION era uno de los slogans más utilizados por los promotores de la Experiencia de Mondragón: la dignidad del trabajador y la emancipación obrera (en definitiva, DEMOCRACIA INDUSTRIAL) eran uno de los fines del pensamiento de este sacerdote de Markina, quien dotó a todas sus premisas y visiones de una alta dosis de realismo, característica definitoria de la Cultura Económica del Cooperativismo Vasco: Arizamendiarrieta propone alcanzar la utopía mediante actos siempre factibles y mundanos. Su influencia en la actual configuración filosófica de Mondragón Corporación Cooperativa es ineludible.

\subsection{Los Valores y Principios Básicos de Mondragón Corporación Cooperativa}

El Grupo Mondragón, como ya he adelantado, posee sus propias pautas destinadas a guiar sus políticas empresariales: MCC se muestra como una corporación con valores y principios propios dotados de una gran importancia, dentro y fuera de las nuestras fronteras. S.K. Saxena y J.G. Craig señalan los principios de Mondragón como uno de los criterios cooperativos más relevantes en el contexto mundial, comparándolos incluso con los de la $\mathrm{ACl}$ y el WOCCU (World Council of Credit Unions) ${ }^{10}$.

La filosofía inspiradora de la Experiencia Cooperativa de Mondragón se constituye mediante tres elementos estrechamente relacionados entre sí: los Principios Básicos, la Misión y los valores Corporativos. Los tres elementos citados conforman los pilares sobre los que se apoyan las Políticas Generales y, en última instancia, el Plan Estratégico de la corporación.

La Cultura Empresarial de MCC y de las cooperativas que la integran, se sustenta, no únicamente pero sí en gran medida, en los Principios Básicos de la Experiencia Cooperativa de Mondragón (aprobados en el primer Congreso Corporativo de 1987). A diferencia de la $\mathrm{ACl}, \mathrm{MCC}$ posee diez principios con los que rige su actuación: los principios de la Alianza Cooperativa Internacional son requisitos

10 Cracogna, Dante (1993), «La Identinad Cooperativa en un mundo cambiante», Anuario de Estudios Cooperativos, Universidad de Deusto, Bilbao. 
que las cooperativas deben cumplir para formar parte de la misma, de tal manera que se constituyen como criterios globales, de carácter general, posibilitando el acceso a su organización a las diferentes experiencias cooperativas mundiales. Los Principios Básicos de la Experiencia de Mondragón definen con mayor precisión los requerimientos de la $\mathrm{ACl}$, a los que indudablemente se adhiere, tomando además como fuente de inspiración la propia Experiencia de Mondragón, inspirada en última instancia por Jose María Arizmendiarrieta. Todo ello hace posible que se puedan apreciar elementos comunes a otras realidades cooperativas, pero también especificidades que dotan a MCC de una personalidad diferenciada.

Del I Congreso Cooperativo de 1987 surgió el siguiente listado de Principios:

1. Libre Adhesión: formar parte de la empresa cooperativa es una opción personal y por tanto, libre; no obstante, son requisitos imprescindibles la aceptación de los Principios y Valores de la Experiencia y la adecuación de las capacidades individuales a la necesidad empresarial del momento.

2. Organización democrática: este principio goza de notable importancia en el contexto de MCC, ya que todas sus cooperativas están integradas mayoritariamente por socios trabajadores (la Experiencia de Mondragón se caracteriza por la naturaleza de sus cooperativas, que pertenecen a la clase de trabajo asociado). Se hace referencia implícita a la Democracia Económica, desdoblando el principio en dos vertientes, la soberanía de la Asamblea General (en la que se cumple el principio clásico de «una persona, un voto») y la elección democrática del Consejo Rector.

3. Soberanía del Trabajo: las empresas de MCC renuncian a la contratación sistemática de trabajadores asalariados, considerando al socio trabajador acreedor esencial de la distribución de resultados (acreedor de la retribución al capital intelectual-el retorno, eje de la cooperativa) y manifestando su voluntad de ampliar las opciones de trabajo a todos los miembros de la sociedad.

4. Carácter instrumental y subordinado del capital: nuevamente se nos muestra la supremacía del factor trabajo; el capital no es sino un mero instrumento para la consecución del fin social de 
la cooperativa. Coincide con el tercer principio de la $\mathrm{ACl}$ (Participación Económica de los Socios).

5. Participación en la gestión: El concepto de Democracia Económica no se agota en el ámbito societario, sino que abarca todo lo relativo a la gestión empresarial de la cooperativa, facilitando los instrumentos para un mayor desarrollo de la autogestión del trabajo por sus propios protagonistas.

6. Solidaridad Retributiva: En MCC, existe un intervalo solidario de retribuciones al trabajo, de manera que el abanico salarial se reduce enormemente si lo comparamos con otro tipo de empresas (me refiero a las sociedades de capitales). Dionisio Aranzadi afirma tajante que la política retributiva de MCC «es más comunista que el propio comunismo».

7. Intercooperación: la Experiencia de Mondragón apuesta por la solidaridad entre cooperativas, entre Agrupaciones de cooperativas y entre movimientos cooperativos vascos, del Estado, europeos o mundiales. Objetivo: potenciar el Movimiento Cooperativo.

8. Transformación social: refleja claramente el pensamiento de Arizmendiarrieta; además, coincide con el principio séptimo de la $\mathrm{ACl}$ (Interés por la Comunidad).

9. Carácter Universal: proclamación de solidaridad con todos los sujetos que colaboren por la Democracia Económica en el ámbito de la Economía Social.

10. Educación: otra nueva muestra de la influencia del padre Arizmendiarrieta, quien proponía transformar la sociedad mediante la «socialización del saber»; coincide plenamente con el quinto principio cooperativo de la $\mathrm{ACl}$.

Como segundo eslabón constituyente de la Estructura Estratégica, la Misión ${ }^{11}$ de la Experiencia de Mondragón recoge los objetivos de orden superior, traduciendo la abstracción de los Principios Básicos en un proyecto tangible y concreto que sirve de inspirador de las políticas generales de la corporación:

«Mondragón Corporación Cooperativa es una realidad socioeconómica de carácter empresarial, con hondas raíces culturales en el

11 Ugarte AzPIRI, Luis Mari, «Mondragón Cooperación Cooperativa, historia de una experiencia», Revista de Estudios de Juventud y Autoempleo, n. ${ }^{\circ}$ 51, Injuve, Madrid. 
País Vasco, creada por y para las personas, inspiradas en los principios Básicos de nuestra Experiencia Cooperativa, comprometida con el entorno, la mejora competitiva y la satisfacción del cliente, para generar riqueza en la sociedad mediante el desarrollo empresarial y la creación de empleo que:

- Se sustenta en compromisos de solidaridad y utiliza métodos democráticos para su organización y dirección.

- Impulsa la participación y la integración de las personas en la gestión, resultados y propiedad de sus empresas, que desarrollan un proyecto común armonizador del progreso social, empresarial y personal.

- Promueve la formación e innovación desde el desarrollo de las capacidades humanas y tecnológicas.

- Aplica un modelo de Gestión propio para alcanzar posiciones de liderazgo y fomentar la Cooperación».

En la actualidad, la Experiencia de Mondragón moldea su gestión empresarial habitual con cuatro Valores Corporativos ${ }^{12}$, que conforman las pautas que caracterizan al citado grupo (valores fijados en el VII Congreso Cooperativo de MCC, el 26 de mayo de 1999); son el núcleo de la cultura empresarial y definen el carácter fundamental de la organización, creando una verdadera identidad diferenciada:

- Cooperación: «Propietarios y Protagonistas». Cooperación se define como la acción común apoyada en la suma de capacidades individuales. Como punto de partida, la empresa cooperativa se entiende como una propiedad colectiva que potencia las capacidades personales e individuales (formación profesional y docencia de los Principios Básicos y Valores Cooperativos), canalizándolas hacia la cooperación en la gestión: el progreso de las partes autónomas (bien sean personas o empresas integradas en MCC) redunda en el desarrollo global de la corporación, prevaleciendo el bien común sobre el individual. En efecto, el ser humano libre se compromete a realizar un trabajo propio autogestionado, integrado en un grupo de trabajo perteneciente a la empresa cooperativa. Esta última coopera a su vez dentro del ámbito corporativo (sexto principio de la $\mathrm{ACl}$ : cooperación entre cooperativas).

12 Zelaia UlíbarRI, Adrián, «La experiencia del Grupo Mondragón», Simposio sobre los Valores de la Cultura Económica del Cooperativismo Vasco, Universidad de Deusto, Bilbao, 289 de noviembre del 2001. Inédito. 
-Participación: "Compromiso en la gestión». Lo esencial y al mismo tiempo, elemento diferenciador del modelo socio-empresarial de las empresas de MCC es la participación entendida en sus dos vertientes, una societaria y otra relativa al ámbito de la gestión (organización del trabajo). La primera hace referencia a los procesos democrático-institucionales derivados del carácter jurídico de la cooperativa, que sirven como instrumento integrador del trabajador en la sociedad donde desarrolla su actividad. La segunda requiere un compromiso, bien por parte del trabajador (persona responsable que interviene en la fijación y consecución de los objetivos de su empresa), bien por parte del equipo directivo (informa, escucha, dota de autonomía al grupo de trabajo y crea estructuras flexibles para poder realizar este determinado estilo de gestión). En las empresas integradas en Mondragón se debe producir un enlace de estos dos ámbitos (ámbito societario y ámbito laboral), garantizando así la participación de sus miembros en tres aspectos: en el capital, en el resultado y en la gestión.

— Responsabilidad Social: «Distribución solidaria de la riqueza e implicación en el entorno». La actividad desarrollada por el conjunto de MCC no posee como única finalidad la obtención desmesurada de rentas: la maximización de beneficios no es único objetivo. El objetivo yace en la búsqueda de la armonía entre el entorno interior cooperativo y su entorno exterior; el desarrollo de la comunidad donde la actividad empresarial se halla enraizada es primordial, «transcendiendo esta actividad al grupo de trabajadores que la desempeñan, incidiendo de modo notable en el entorno más próximo, mejorándolo»: desarrollo cooperativo-desarrollo sostenible. En el VII Congreso Cooperativo de MCC se añade textualmente: "se impulsará el acceso de las personas de nuestra área de influencia a condiciones socio-laborales equivalentes a las de los socios cooperativistas». Analizaré el cumplimiento en la práctica de esta declaración de intenciones en el proceso de expansión llevado a cabo por el Grupo Eroski, más concretamente, en el funcionamiento de GESPA, S.C.P.

—Innovación: «Renovación permanente». En primer lugar, la innovación se nos muestra en el plano individual, como el esfuerzo desarrollado por la entidad empresarial a la hora de formar e implicar a las personas libres en el proyecto común de la cooperativa. El desarrollo personal y profesional es sinónimo de renovación 
y aceleración del cambio. En el plano empresarial, el progreso se logra mediante «una actitud permanente de búsqueda de nuevas opciones en todos los ámbitos de actuación de las diferentes cooperativas, empujándolas en la experimentación de nuevas soluciones». Nuevas soluciones y contundentes opciones son las que, en general, el derecho cooperativo y, en particular, el Grupo Eroski ha aplicado a los obstáculos hallados en su camino.

Las especificidades de la Experiencia del Grupo Mondragón se haIlan estrechamente relacionadas con la naturaleza de las empresas que la integran, pertenecientes a la tipología de cooperativas de trabajo asociado: sus valores aparecen ligados a la Democracia económi$\mathrm{ca}$, siendo clara la influencia del pensamiento de Arizmendiarrieta. Estos parámetros (la Filosofía Inspiradora de la Experiencia del Grupo Mondragón) son los más precisos y adecuados para analizar las posibles desviaciones de la increíble y necesaria expansión de Eroski, con respecto a los valores clásicos del cooperativismo.

\section{Problemática de la Búsqueda de Financiación Externa en la Sociedad Cooperativa: los peligros de «Desnaturalización» y "Desmutualización"}

«Para las sociedades cooperativas, en un mundo cada vez más competitivo y riguroso en las reglas de mercado, la competitividad se ha convertido en un valor consustancial a su naruraleza cooperativa». De esta manera recoge la Ley Estatal de Cooperativas en su Exposición de Motivos la gran importancia que adquieren los valores de eficacia y rentabilidad (necesarios para el adecuado posicionamiento de cualquier empresa en el mercado) dentro de la propia Identidad Cooperativa. Lo cierto es que el cooperativismo está obligado a ser competitivo. Debe serlo si desea sobrevivir en un entorno donde cohabitan infinidad de grandes empresas, ubicadas todas ellas en un nuevo contexto de competencia13: "la sociedad cooperativa tiene que poder situarse en dicho mercado con idénticas posibilidades que el resto de

\footnotetext{
13 Para esta pequeña introducción hemos utilizado, además del material facilitado por la profesora Laura Gomez Urquijo en su módulo «el Caso de Eroski» (integrado en el curso de Especialización en Estudios Cooperativos de la Universidad de Deusto, Bilbao, 2002), un artículo escrito conjuntamente por la misma profesora y Marta de los Ríos Añón: "Respuestas a las dificultades de Captación de Capital en las Cooperativas: El Caso de Eroski», Anuario de Estudios Cooperativos de la Universidad de Deusto, Bilbao, 1997.
} 
las empresas con las que debe competir» (Exposición de Motivos de la Ley 4/93, de 24 de junio, de Cooperativas de Euskadi).

Para lograr ese imprescindible posicionamiento competitivo, las sociedades cooperativas necesitan lograr una dimensión empresarial adecuada: la obligación de hacer frente a la demanda del nuevo (y enorme) mercado, hace necesaria la adquisición de un tamaño empresarial adecuado y suficiente. Se produce la inevitable concentración de empresas, que a su vez "conduce a una creciente concentración de riqueza y poder en manos de grandes entidades multinacionales y a una creciente pauperización del grueso de los consumidores, de los trabajadores y de los pequeños y medianos productores» ${ }^{14}$. Aparece aquí reflejado el Principio del Reforzamiento Empresarial, el cual obliga a toda empresa, sea sociedad de capital o cooperativa, a engrandecer su dimensión y extenderla hasta poder hacer frente a su competencia más directa: en el caso de la sociedad cooperativa, este crecimiento necesario puede contradecir los valores y principios de funcionamiento clásicos de origen rochdaleano, ya que no pocas veces habrá que contar con capital externo a la cooperativa para poder desarrollar este proceso de expansión (en el modelo clásico, todo el capital es aportado por los socios y es íntegramente de su propiedad); además, en otras muy contadas ocasiones, esta expansión se realizará a través de un modo ajeno al cooperativo (como el desarrollado por el grupo Eroski): el Principio de Refuerzo Empresarial se nos muestra en toda su extensión, primando los intereses económicos y empresariales sobre los requerimientos sociales o cooperativos ${ }^{15}$.

Un factor de suma importancia en la concreción del nuevo contexto de competencia en el que las cooperativas desarrollan su actividad es la integración de las mismas en mercados de elevado tamaño donde rigen las reglas de protección del llamado «libre juego»: el derecho extiende su ámbito a la defensa de la libre competencia en el mercado, se halle éste ubicado en la Unión Europea (mercado europeo) o en un contexto global (mercado internacional). La normativa de control abarca tanto las concentraciones empresariales equiparables a situaciones de monoplio o oligopolio, como las subvenciones estatales; las cooperativas, habituales destinatarias por parte de los diferentes estados

14 Kaplan de Drimer, Alicia (1999), «El Rol del Cooperativismo en el próximo milenio», Anuario de Estudios Cooperativos, Universidad de Deusto.

15 Dacosta Constan (1991), «Eroski, una adaptación al cambio», Anuario de Estudios Cooperativos, Universidad de Deusto. 
de ayudas de índole económico, se ven afectadas por este tipo de restricciones que garantizan tanto los derechos del consumidor, como los derechos de las demás empresas a desarrollar su actividad en igualdad de condiciones. Esta igualdad en el mercado es la que hace necesaria para las sociedades coperativas una mayor búsqueda de recursos financieros con los que poder posicionarse en el mercado en una situación competitiva adecuada. Los instrumentos que posibilitan esta captación de capital adquieren una importancia esencial, no sólo por su efectividad para con el desarrollo empresarial, sino también por su incidencia en los valores informadores de la actividad cooperativa.

Como a continuación analizaremos, la sociedad cooperativa posee ciertas dificultades a la hora de lograr la financiación necesaria para el adecuado desarrollo de su actividad: en ciertas ocasiones, su capacidad de autofinanciación (recursos financieros provenientes de los propios socios) es insuficiente, ya que la figura del socio cooperativista se identifica en la mayoría de los casos con el «trabajador de clase media», incapaz de aportar los recursos suficientes, dada su limitada capacidad de ahorro; por lo tanto, la cooperativa se ve obligada a acceder al mercado de capitales tratando de lograr financiación externa; es necesario para el logro de este tipo de recursos, adaptar la legislación cooperativa a los nuevos requerimientos, introduciendo instrumentos correctores que faciliten la captación de capital externo, con la posibilidad de producirse una cierta desvirtuación del modelo cooperativo, mediante los procesos de «desnaturalización» y «desmutualización», tan arduamente advertidos por la Doctora Alicia Kaplan de Drimer.

\subsection{Las dificultades de acumulación y captación de capital en las So- ciedades Cooperativas}

La sociedad cooperativa se encuentra dos importantes obstáculos que dificultan enormemente el desarrollo de su actividad en el mercado: estos dos aspectos, los dos relacionados con el tratamiento dado al capital en la empresa cooperativa, entorpecen el posicionamiento de ésta frente a la sociedad anónima, negándole a la primera competir en plena igualdad de condiciones con la segunda. Estas dos dificultades son, respectivamente, la variabilidad del capital cooperativo y la obligada restricción en sus derechos de gestión con que se limita al capital externo en el ámbito cooperativo. 
1. La Variabilidad del Capital: el peligro de descapitalización en la cooperativa. Las cooperativas han sido definidas como sociedades de capital variable, teóricamente, algo intrínseco o esencial a las cooperativas de trabajo asociado. Más concretamente, esta característica de variabilidad viene determinada por el Principio Cooperativo de Puertas Abiertas o Libre Adhesión. Las personas que se adhieran al proyecto empresarial cooperativo deben desembolsar un capital mínimo, requisito indispensable para adquirir la correspondiente condición de socio. No obstante, dicho principio posibilita al socio romper los lazos con que se ha unido a la sociedad cooperativa: además de separarse legalmente, su participación en el capital le es devuelta, por lo que la cooperativa se encuentra ante un grave peligro de Descapitalización.

Los acreedores sufren una evidente pérdida de su garantía, que es el capital social de la empresa y por lo tanto, se produce una inestabilidad inexistente en la sociedad anónima: este defecto de la estructura financiera cooperativa puede poner en peligro el adecuado desarrollo de la propia actividad cooperativa dentro del mercado, no pudiendo competir en igualdad de condiciones con las empresas eminentemente capitalistas. Al fin y al cabo, nos encontramos ante un problema de confianza, ya que la cifra de capital social de la empresa cooperativa, dada su potencial variabilidad, no ofrece credibilidad al inversor. Conclusión: dificultad de acceso al mercado de capitales, dificultad de acceso a fuentes externas de financiación ${ }^{16}$.

Frente a esta dificultad de capitalización de la sociedad cooperativa, encontramos diversas respuestas que tratan de paliar este grave problema: por lo tanto, queda patente que la variabilidad de los socios, promulgada por el Principio de Puertas Abiertas, no implica necesariamente la variabilidad del capital. Estas respuestas que hemos apuntado se centran en la fijación de un capital social mínimo y de una participación máxima de cada socio en dicho capital, fijación de un período mínimo de permanencia en la cooperativa, fijación de un período máximo para la devolución del capital perteneciente al socio que abandona la cooperativa y la constitución de fondos de capital fijo con aportaciones voluntarias de terceros no socios, por vía legal o estatutaria (la sociedad cooperativa

16 Zelala UlíbARRI, Adrián (1992), «Capital y Sociedad Cooperativa», Madrid, páginas $159-168$. 
pasaría a ser una sociedad de capital mixto, es decir, una empresa de capital variable y fijo) ${ }^{17}$.

\section{Limitaciones de financiación intrínsecas a la identidad cooperativa tradicional: la postura ortodoxa y la problemática del capital sin derechos societarios. Con el término Ortodoxia Coo- perativa quiero hacer referencia a la rama del pensamiento que fiel- mente sirve a los valores clásicos cooperativos inspirados por los pio- neros de Rochdale. Según esta concepción de la sociedad cooperativa, su estructura financiera se constituye como un modelo cerrado en el que los socios son los únicos que aportan capital a la co- operativa. El capital externo no tiene cabida en la sociedad cooperati- va clásica: se hace así referencia a un proyecto totalmente autogestio- nado por las personas que «voluntariamente se han unido para satisfacer sus necesidades y aspiraciones económicas, sociales y cultu- rales en común mediante una empresa de propiedad conjunta y de gestión democrática».}

En la actualidad es casi imposible concebir una empresa realmente competitiva financiada íntegramente con las aportaciones de sus socios: en ciertos sectores en los que, para el adecuado desarrollo de la actividad empresarial, es necesario realizar una importante inversión de capital, este modelo cerrado de empresa cooperativa ha quedado obsoleto. Para poder posicionarse en un mercado concurrencial, la sociedad cooperativa ha evolucionado, flexibilizando su estructura financiera y adecuándose a los nuevos requerimientos de competitividad: terceros no socios pueden colaborar, con su aportación al capital, a la realización del objeto social de la cooperativa.

No obstante, y a diferencia de la sociedad anónima, la sociedad cooperativa no concedía al capital derecho político alguno. "Una persona, un voto» es la más clara muestra del Principio Cooperativo de Gestión Democrática por parte de los Socios. El capital es un mero instrumento para la consecución del fin social de la cooperativa, por lo que no se le dota de capacidad política para decidir aspecto alguno sobre la marcha de la sociedad: claro ejemplo del carácter personalista de la entidad cooperativa. El inversor aportaba su capital con la finalidad de lograr una adecuada rentabilidad, pero no ejercía ningún control sobre la gestión empresarial de la sociedad, ya que su inversión

17 Zelaia Ulíbarri, Adrián (1995), «Acceso de las Cooperativas al Mercado de Capitales», Instituto Nacional de Fomento de la Economía Social, Mondragón, páginas 62-64. 
era materializada mediante instrumentos jurídicos no societarios (por ejemplo, los préstamos y la adquisición de obligaciones emitidas por la cooperativa). Este aspecto es, a nuestro parecer, uno de los mayores obstáculos para que las cooperativas puedan acceder en igualdad de condiciones al mercado de capitales: se trata de un claro problema de confianza, ya que en las inversiones cuya retribución no está determinada de forma fija, el inversor desea tener ciertas garantías de que su aportación al capital va a ser retribuida de forma satisfactoria ${ }^{18}$.

Es habitual en las sociedades de capital que el inversor ostente derechos políticos en los órganos sociales, constituyendo así la garantía necesaria para asegurar la rentabilidad de la inversión efectuada: los derechos sociales le confieren control sobre la entidad receptora de su capital (en caso de ser accionista mayoritario), de tal manera que podrá dirigir las operaciones empresariales como mejor convenga a la rentabilidad de su inversión. La sociedad cooperativa carecía de estos instrumentos con los que asegurar la confianza de inversores externos: la estricta observancia de los valores de Igualdad y Democracía se lo impedían.

En los siguientes puntos analizaremos las nuevas figuras jurídicas destinadas a la captación de capital mediante el otorgamiento a los inversores de derechos sociales propios de los cooperativistas. Estos novedosos instrumentos fortalecen la estructura financiera de la cooperativa; no obstante, entrañan un cierto peligro de privatización de la entidad de propiedad colectiva, peligro expresado en sus dos vertientes, los procesos de "DESNATURALIZACION» y la «DESMUTUALIZACION».

2.2. Peligrosidad de los mecanismos correctores del Derecho Cooperativo en materia de financiación: los procesos de «Desnaturalización» y «Desmutualización». La privatización de la Sociedad Cooperativa

Para poder competir adecuadamente en un mercado concurrencial como el actual, el legislador tuvo que subsanar, parcialmente al menos, la deficiencia expuesta en el punto inmediatamente anterior, es decir, la dificultad de captación de capital proveniente de inversores

18 Zelala Ulíbarrl, Adrián (1992), op. cit., páginas 192-194. 
ajenos a la cooperativa, mediante el refuerzo de los instrumentos societarios de financiación de las sociedades cooperativas: nos referimos a figuras jurídicas que refuerzan la cofianza del inversor, confiriendo derechos sociales a personas ajenas a la actividad cooperativizada.

En efecto, el Derecho Cooperativo ideó un sistema en el cual los capitalistas podían ejercer derechos políticos en los órganos societarios de la empresa cooperativa, ya que se introducían en ella en calidad de socios no usuarios, creándose de esta manera otro tipo de socio cooperativista, junto a las demás clases de asociados. La concesión de derechos políticos aumenta la confianza del inversor en la seriedad con la que la cooperativa gestionará sus inversiones: garantiza de esta manera la rentabilidad de sus aportaciones, ya que considera el derecho de voto en la Asamblea General como un mecanismo de control de la evolución de su inversión ${ }^{19}$.

Hablamos del Ilamado Socio Colaborador, denominación con que se le dota en la Ley 27/99, de julio, de Cooperativas, a «aquellas personas físicas o jurídicas, públicas o privadas, que, sin poder desarrollar la actividad cooperativizada propia del objeto social de la cooperativa, pueden contribuir a su consecución». Una figura similar encontramos en Italia, en la Ley de 31 de enero de 1992, en la cual se regulan las acciones del Socio "Inversor» no usuario, que son aquellos cuya relación societaria se limita a una aportación de capital, percibiendo en contraprestación la titularidad de derechos de voto en la Asamblea General. Otros proyectos de reformas proyectados permiten que las aportaciones de esta clase de socios confieran el derecho a participar en órganos de gestión y control, consten en títulos endosables y se ofrezcan a asociados, a terceros o en oferta pública y que en caso de liquidación de la cooperativa, se reembolsen esas inversiones con preferencia a las cuotas sociales de los socios cooperativistas ${ }^{20}$. Por lo tanto, nos estamos refiriendo a un inversor que, efectuando una aportación al capital, se introduce en los diferentes órganos societarios, es decir, se «adentra» en la cooperativa en calidad de socio, equiparándose en derechos con el resto de asociados: se trata estrictamente de un «socio de la cooperativa» y su capital es calificado como recurso propio de la entidad, aunque «tradicionalmente» este nuevo asociado

19 ZelaIA UlíbARRI, Adrián (1995), op. cit., páginas 116 y siguientes.

20 KaPLAN DE DrIMER, Alicia (1998), op. cit. 
no se identifique con el originario concepto de socio establecido por los Pioneros de Rochdale, por lo que su aportación será considerada, a efectos de este trabajo, como capital proveniente de inversores externos a la entidad y ajenos a los intereses cooperativos. Pudiera darse el caso de que este inversor fuese otra entidad cooperativa asociada a la anterior: realiza una aportación al capital con la intención de reforzar la actividad empresarial de la destinataria. Este un claro ejemplo del Valor de la Solidaridad en el ámbito cooperativo, materializado en el sexto principio de la $\mathrm{ACl}$, Cooperación entre Cooperativas. Con el concepto «Desnaturalización» no aludimos a esta clase tan beneficiosa de inversión, ni siquiera a las aportaciones realizadas por pequeños inversores, minoritarios y sin real poder de decisión en los órganos societarios (aunque, analizando la estructura tradicional cooperativa, sí puede producirse un cierto grado de «Descooperativización»). En este trabajo nos referimos exclusivamente a socios «inversores» no usuarios que ostentando una notable mayoría en los órganos de decisión (o aun sin ser mayoritarios, cuando los demás asociados no concentren sus votos) controlen la sociedad cooperativa.

Dicha atribución de derechos implica una alarmante "Desnaturalización» o «Descooperativización» de la empresa, ya que debilita el carácter personalista de la misma, relacionando el derecho de voto con la aportación al capital. Se produce, por tanto, una pérdida de la identidad cooperativa clásica, creándose en el seno de la entidad dos grupos que en ocasiones pueden resultar diametralmente antagónicos: por un lado, los socios cooperativistas que realizan la actividad propia del objeto social, preocupados por la buena marcha de la sociedad cooperativa, por la calidad de los servicios prestados y por la cobertura de sus necesidades económicas, sociales y culturales; por otro lado, los inversores-capitalistas preocupados únicamente por la rentabilidad de sus aportaciones al capital, por tanto, despreocupados de la actividad cooperativizada. Existe la posibilidad de que la cooperativa, sea controlada íntegramente por el capital y, al igual que cualquier sociedad anónima, trate de maximizar sus beneficios únicamente con la intención de maximizar también la rentabilidad de las aportaciones de los «accionistas», dirigiendo sus operaciones en el mercado hacia dicho fin: todo ello perjudicando los intereses de los asociados. Otra fatal posibilidad, es que, a traves de maniobras internas haciendo uso de sus derechos políticos, los socios «inversores» provoquen la disolución y liquidación de la entidad cooperativa, apoderándose de las re- 
servas acumuladas por la cooperativa ${ }^{21}$. Todo estos perniciosos procesos se llevarán a cabo siempre que el inversor-capitalista sea "accionista» mayoritario o que utilice a su favor las dificultades prácticas propias del ejercicio de la democracia (por ejemplo, la no-asistencia de algunos asociados a las asambles generales y la dispersión de las opiniones o intereses de los socios venciendo los votos del «accionista no mayoritario»).

El proceso de «Desnaturalización» o «Descooperativización», como ya hemos adelantado, se puede llegar a entender como una «Privatización» de la sociedad cooperativa, perdiendo su identidad cooperativa clásica y llegando incluso al extremo de "cotizar sus acciones en bolsa» (un simbólico ejemplo que relaciona a la cooperativa estrechamente con las sociedades de capitales): «El término privatización, cuando se aplica a las cooperativas, se utiliza para definir la relación de propiedad en el contexto económico de las cooperativas; en las cooperativas privatizadas, los capitales y el control anteriormente en poder de los productores, son ahora compartidos con sectores privados que no representan los intereses de los trabajadores. Para sobrevivir a largo plazo, una cooperativa privatizada tendrá que enfocar sus negocios para aumentar al máximo sus ganancias y poner menos atención en brindar altos niveles de servicios a sus asociados 22 》.

Nos encontramos ante un grave y peligroso «atentado» contra los Valores y Principios Cooperativos, contradiciendo las clásicas normas de organización y funcionamiento de origen rochdaleano. Recordemos la definión de empresa cooperativa realizada en el congreso de la $\mathrm{ACl}$ en 1995: "Una cooperativa es una asociación de personas que se han unido voluntariamente para satisfacer sus necesidades y aspiraciones económicas, sociales y culturales en común mediante una empresa de propiedad conjunta y de gestión democrática». Más aun, teniendo en cuenta los valores intrínsecos al cooperativismo vasco, estrechamente ligados a la cooperativización del trabajo y a la Democracia Económica, este proceso de «desnaturalización» (derivado de la intromisión de terceros ajenos a la entidad en

21 Kaplan de Drimer, Alicia (2000), «Las Cooperativas ante los peligros de "Desnaturalización"y "Desmutualización"», Anuario de Estudios Cooperativos, Universidad de Deusto, Bilbao.

22 KAPLAN DE Drimer, Alicia (1998), «Globalización: la Reestructuración de la Industria del Trigo Canadiense», Revista de la Cooperación Internacional, n. ${ }^{\circ} 31$. 
calidad de «accionistas» con control mayoritario sobre la misma) vulnera su más profunda esencia y tradición.

En cuanto a los Valores Universales proclamados por la ACl, este proceso lesiona el Valor de la lgualdad, ya que el capital deja de ser un mero instrumento posicionándose en un plano de supremacía y control sobre el epicentro de la identidad cooperativa, el trabajo: Los asociados que desarrollan la actividad cooperativizada se encuentran en una posición inferior con respecto a los socios «inversores», equiparándose directamente a los trabajadores por cuenta ajena de la sociedad de capitales. Las necesidades del grupo dominante son cubiertas; en cambio, los requerimientos de los demás asociados siguen tal cual estaban, a pesar de que son ellos los que con su trabajo (en el caso de la cooperativa de trabajo asociado) sostienen básicamente la empresa de propiedad «colectiva». "A cada uno lo que se merece»: lesionado queda el Valor de la Equidad, ya que los «beneficios» obtenidos («Excedentes» en el idioma cooperativo) por el factor capital pueden llegar a ser superiores a los retribuidos al resto de asociados. Además, el Valor Democracia también se ve afectado, ya que los asociados que aportan sus servicios activamente a la cooperativa, no participan de manera potencialmente activa en la vida societaria de la cooperativa, ahora gobernada, como antes hemos apuntado, por los socios «inversores» no usuarios. Y es que frente al Principio Cooperativo de Autonomía e Independencia establecido por la $\mathrm{ACl}$ ha prevalecido en ciertos casos el Principio de Refuerzo Empresarial, garantizando así los recursos financieros de la entidad. El citado Principio de Autonomía e Independencia cooperativa fue una figura innovadora del congreso de 1995 de la $\mathrm{ACl}$, en el que se señaló que «las cooperativas son organizaciones autónomas de autoayuda, gestionadas por sus socios» y citando expresamente que «si consiguen capital de fuentes externas, lo hacen en términos que aseguren el control democrático por parte de los socios y mantengan su autonomía cooperativa». Observamos en el quebrantamiento de este precepto el encuadre definitivo a nuestro problema de «Desnaturalización».

La incidencia de dicho proceso privatizador en el seno de la empresa cooperativa, afecta directamente a la esencia última del Cooperativismo Vasco: ya que al tomar como valores básicos el Trabajo y la Solidaridad («Lana-Kidetza = Lankidetza»²3, es decir, «Trabajo-Solidaridad

23 LANKI, lankidetzaren ikertegia (1999), «Lankidetza. Arizmendiarrietaren eraldaketa proiektua», Lanki ikertegia, Mondragon Unibertsitatea, Arrasate-Mondragón, páginas 104-105. 
= Cooperativismo»), elementos inherentes a las cooperativas de trabajo asociado, la «desnaturalización» de sus normas tradicionales de funcionamiento provoca una grave lesión en estos dos pilares de su filosofía.

Los valores intrínsecos al pensamiento de Arizmendiarrieta siguen vigentes en la actual concepción de cooperativismo vasco desarrollada en Euskadi: el concepto «Trabajo y Unión» inspira buena parte de la filosofía informadora de la Experiencia de Mondragón, reflejándose en sus propios valores y principios. Destacamos la contradicción aparente que sufren dichos cimientos filosóficos ante el peligro de «Desnaturalización»: por un lado, encontramos el Principio de Soberanía del Trabajo, centrado exclusivamente en la condición de supremacía del factor trabajo, al que se le da una importancia capital, promoviendo la captación de socios trabajadores (los propietarios de la empresa), renunciando a la captación sistemática de trabajadores asalariados; por lo tanto, el siguiente principio, el Carácter instrumental y subordinado del capital, es una consecuencia directa del anterior: dada la supremacía del factor trabajo, el capital se constituye como un simple instrumento para el logro de los fines de los socios cooperativistas, negándole, de este modo, la participación directa en la gestión empresarial, ni tampoco en los resultados obtenidos. Conceder derechos societarios a los inversores no vinculados con la cooperativa vulnera estos dos principios.

De igual modo, los Valores Corporativos de Cooperación («Propietarios y Protagonistas») y Participación («Compromiso en la gestión») se ven ciertamente atenuados por este proceso de privatización de la sociedad cooperativa: el Valor Cooperación entiende la empresa como una «propiedad colectiva, donde el ser humano libre se compromete a realizar un trabajo propio autogestionado», es decir, el pilar básico de la entidad es nuevamente el factor trabajo, el cual ejerce una capacidad autogobernante de su propia labor. Por su parte, el Valor Participación amplía la toma de decisiones del trabajador al ámbito de la propia gestión de la empresa, superando el ámbito societario. Estos dos valores conforman una posible síntesis del pensamiento de Arizmendiarrieta, ya que perfectamente se pueden enmarcar en su concepto "Trabajo y Unión»: la Ilamada "autogestión y autoemancipación obrera» ${ }^{24}$ es un fin al que ha tendido continuamente el movimiento cooperativo vasco, siendo prueba inequívoca de ello la

24 Salaberria Amestl, Javier, "Los Valores del Moviemiento Cooperativo Vasco», Simposio sobre los valores de la cultura económica del cooperativismo vasco, Universidad de Deusto, 28 de noviembre de 2001. Inédito. 
elevada cooperativización del trabajo de la que hace gala, eso sí, aplicada a toda clase de sociedades cooperativas, no sólo a cooperativas de trabajo asociado (es el caso de Caja Laboral, cooperativa de crédito y de Eroski, cooperativa de consumo). En conclusión: si a un inversor, por el simple hecho de realizar una aportación al capital y sin poseer ninguna otra vinculación con la entidad, le fuese permitido ejercer los mismos derechos societarios que ostenta cualquier cooperativista de la empresa, inmiscuyéndose así en el proyecto autogestionado que es la cooperativa, se vulneraría sin duda alguna, no sólo el sistema de valores y principios antes citados, sino también la más profunda tradición cooperativa vasca.

A nuestro parecer, relacionado con el peligro anteriormente citado, hallamos la peligrosidad del proceso de "Desmutualización", consistente en que «una entidad cooperativa o mutual sea transformada en una sociedad anónima o en algún otro tipo de entidad de propiedad particular» ${ }^{25}$. Nos referimos al caso en que la entidad cooperativa efectúa la «conversión» de su forma jurídica en una sociedad de capitales, por razones tanto internas como externas a la misma:

- Por necesidad empresarial: Una razón externa a la cooperativa puede ser la extrema competencia habida en el mercado concurrencial actual, obligándola a idear nuevas formas de captación de capital. Cuando una entidad de tales características carece de medios suficientes para hacer frente a sus problemas de financiación, una posible solución sería la transformación de la cooperativa en una sociedad por acciones, de tal manera que podría obtener los recursos suficientes para el desarrollo de su actividad empresarial. En definitiva, la conversión iría destinada a dotar a la empresa de recursos suficientes para sobrevivir en el mercado. No obstante, este tipo de sociedades renunciarán tarde o temprano a los valores cooperativos que las habían caracterizado en el pasado. Es el caso de las compañías de seguros mutuales de los Estados Unidos de América, que están considerando la posibilidad de efectuar dicha conversión con la finalidad de lograr suficiente capital externo para aumentar sus operaciones comerciales ${ }^{26}$. De llevarse a cabo tal transformación, la entidad se volcaría en la búsqueda prioritaria del beneficio de los accionistas, dejando a un lado la satisfacción de las necesidades de los anteriormente cooperativistas.

25 Kaplan de Drimer, Alicia (2000), op. cit.

26 Noticia $A C l, n .^{\circ} 2$, página 5 , de 1997, traducida al castellano por IMNTERCOOP, Editora Coopertativa Ltda., Argentina. 
No obstante, cabe la posibilidad de que estas nuevas sociedades anónimas actúen "de hecho» como sociedades cooperativas, manteniéndose en poder de los antiguos cooperativistas la mayoría de las acciones de la empresa: es el caso de las Sociedades Anónimas Laborales (en la que el $50 \%$ del capital se halla en manos de los trabajadores) y de las Sociedades de capitales "Cooperativizadas» mediante las ESOP (Employee Stock Ownership Plans-Planes de Adquisición de capital por los Empleados). En tal caso, estas nuevas entidades podrán actuar adheridas a los Valores Cooperativos, con una cierta atenuación de su identidad inicial, pero garantizando, en cierta medida, la captación de capital externo; apuntamos que podrán lograr «en cierta medida» la financiación necesaria, ya que este tipo de sociedades de capital «cooperativizadas» tienden a maximizar las retribuciones del factor trabajo y minimizar las del capital (perjudicando la rentabilidad de las acciones). Con este efecto se logra una natural desconfianza en los inversores, de manera que volvemos nuevamente a la situación inicial: dificultad de financiación de la cooperativa dada la falta de garantía-derechos sociales reconocidos al inversor ${ }^{27}$.

(Otra causa de «Desmutualización» se produce cuando tanto fuerzas internas de la cooperativa (ciertos asociados con intereses en la transformación de la entidad) como fuerzas externas a la misma (capitales particulares) se ponen de acuerdo para que tal "privatización» (conversión en sociedad de capitales) se lleve a cabo. El problema se acentúa cuando los aliados internos son los asociados «inversores» no usuarios, facilitadores de la introducción de capital e «intereses» externos a la cooperativa. La finalidad de dicha transformación puede consistir, simplemente, en facilitar la absorción de la cooperativa por otras grandes empresas del mismo sector: adentrarse en una sociedad anónima es sumamente más sencillo para un poderoso inversor que desee, a toda costa, hacerse propietario de una de sus directas competidoras. Nos hallamos ante un posible instrumento de concentración empresarial. Este es el caso de la federación de cooperativas de consumo C.W.S. (Co-operative Wholesale Ltd.) de Gran Bretaña ${ }^{28}$, que a punto estuvo de ser "desmutualizada» mediante las maniobras malintencionadas de la compañía "Galileo», la empresa "Lanica» y el «Banco Hambros». Estas empresas intentaron, sin éxito, comprar la citada

27 Zelaia UlíbarRI, Adrián (1995), op. cit., páginas 91-92.

28 Kaplan Drimer, Alicia (1998), «Enemigos Invisibles: El Caso de C.W.S. de Gran Bretaña», Anuario de Estudios Cooperativos, Universidad de Deusto, Bilbao. 
federación inglesa mediante aliados internos interesados en la transformación de su cooperativa.

- Encontramos otra razón para efectuar la conversión en los intereses de ciertos capitales particulares en apoderarse de las reservas de la cooperativa (generalmente, cuando dichas reservas superen la totalidad del capital aportado por los socios) una vez realizada la transformación: como contraprestación, los asociados podrían percibir el beneficio logrado mediante la transmisión de sus acciones en bolsa. Este es el caso de las denominadas «building societies», entidades cooperativas que recogen el ahorro popular para destinarlo a préstamos concedidos a sus asociados, de tal modo que éstos puedan hacer frente al pago de sus viviendas. Algunas de estas cooperativas se salvaron mediante el rechazo a tal conversión expresado por los asociados en la Asamblea General: es el caso de «Nationwide».

Estos procesos anulan contundentemente la identidad cooperativa, ya que las sociedades cooperativas «totalmente privatizadas», es decir, las cooperativas transformadas en sociedades de capitales, una vez adquirida la estructura jurídica «capitalista», abandonarán tarde o temprano su esencia cooperativa.

Ahora bien, existen instrumentos legislativos que impiden que la sociedad cooperativa se «desmutualice»: uno de ellos es la prohibición expresa por ley de permitir a estas entidades transformarse en sociedades anónimas u otro tipo de sociedades de propiedad particular. Otro instrumento consistiría en proclamar, también por ley, la irrepartibilidad de las reservas sociales en caso de disolución, liquidación e incluso transformación de la cooperativa, reembolsando a los asociados únicamente las aportaciones efectuadas por ellos mismos al capital. La irrepartibilidad de las reservas sociales es ampliamente discutida por una parte importante de la doctrina (de postura heterodoxa), la cual añade que la capitalización y el posterior uso de estas reservas por parte de los socios es claramente beneficiosa para los mismos, señalando a continuación que este hecho en nada debilita la esencia última del cooperativismo.

No obstante, como constataremos en los siguientes puntos, no es en absoluto sencillo posicionarse ante los graves problemas financieros de las sociedades cooperativas: adoptar una postura ortodoxa, manteniendo la rigidez de la estructura cooperativa (y en consecuencia, también de sus valores), o asumir un talante heterodoxo, flexibili- 
zando las normas de funcionamiento de origen rochdaleano con el fin de adaptar la entidad cooperativa a los nuevos tiempos (de modo que ésta pueda sobrevivir en un competitivo mercado concurrencial).

2.3. El peligro de «Privatización» en la Legislación Española: breve análisis de los instrumentos societarios de captación de capital externo y de las figuras jurídicas facilitadoras del proceso de «Desmutualización»

Con la intención de efectuar un simplificado análisis que nos muestre cuáles son las posturas adoptadas por los diferentes legisladores ante la problemática objeto de este trabajo, a efectos del mismo, centraremos la determinación de los procesos «Privatizadores» en dos leyes sumamente importantes: en primer lugar, la Ley 27/99, de 16 de julio, de Cooperativas, es decir, la norma estatal reguladora de las cooperativas que desarrollen su actividad en el territorio de varias Comunidades Autónomas (este es el caso de Eroski y otras empresas de MCC, como Maier, Irizar, Fagor y Urssa), excepto cuando una de ellas se desarrolle con carácter principal; esta ley actúa también con supletoriedad en todos aquellos casos en que la ley autonómica incurra en un vacío legal. Este estudio legislativo lo completaremos mediante el análisis de la Ley 4/93 de junio, de Cooperativas de Euskadi, modificada por la Ley 1/2000, de 29 de junio: la Ley vasca, debido en gran medida a la flexibilidad con que dota al aspecto financiero cooperativo, ha constituído la fuente de inspiración de otras muchas reformas llevadas a cabo en diferentes comunidades autónomas del Estado, e incluso ha actuado como modelo a la hora de conformar la Ley estatal. Este motivo, y su evidente relación con los valores del cooperativismo vasco, nos ha obligado a incluirla ineludiblemente en el presente trabajo.

La Ley 27/99, de julio, de Cooperativas muestra un cierto cambio frente a su predecesora (Ley 3/87, general de Cooperativas), centrando todo su ímpetu en el refuerzo de la naturaleza empresarial de la sociedad cooperativa: para ello, crea diversas fórmulas jurídicas que se constituyen como «sólidos soportes» para la consolidación de su posición competitiva en el mercado. Y es que «la competitividad se ha convertido en un valor consustancial a su naturaleza cooperativa, pues en vano podría mantener sus valores sociales si fallasen la eficacia y rentabilidad propias de su carácter empresarial»: la Exposición de Motivos trata continuamente de «compatibilizar los requisi- 
tos de rentabilidad y competitividad con los valores que dan forma a las cooperativas desde hace más de ciento cincuenta años». Como más adelante veremos, esta adecuación de los valores rochdaleanos al Principio de Reforzamiento empresarial se hace difícilmente realizable.

De esta manera, la Ley de Cooperativas estatal se conforma, mediante esos nuevos «sólidos soportes» a los que hemos hecho referencia, como un «Instrumento jurídico válido para hacer frente a los grandes desafíos económicos y empresariales que representan la entrada en la Unión Europea». No obstante, como habíamos adelantado, estas nuevas figuras se materializarán en un distanciamiento de las tradicionales normas organizativas utilizadas, hasta entonces, por el cooperativismo.

Por su parte, la Exposición de Motivos de la Ley 4/93, de 24 de junio, de Cooperativas de Euskadi, adquiere el mismo talante innovador y flexibilizador, "con el objetivo de que éstas puedan situarse en el mercado con idénticas posibilidades que el resto de las empresas con las que deben competir». Haciendo directa referencia al régimen económico aplicable, dicha Exposición de Motivos afirma tajante que el legislador "ha tratado de establecer un marco de actuación flexible que permita a las cooperativas contar con la adecuada financiación propia, mejorando el tratamiento del capital social, a la vez que acudir a nuevas fórmulas de financiación». De igual modo, la Exposición de Motivos de la Ley 1/2000, de 29 de junio, de Modificación de la Ley de Cooperativas de Euskadi, señala que la Ley 4/93 dota al moderno cooperativismo vasco de «una mayor agilidad para que las cooperativas puedan competir en un mercado como el actual, caracterizado por su cambio permanente». Además se equipara a la Ley estatal, en cuanto que trata de congeniar la identidad cooperativa y los retos empresariales, «mediante una cobertura legal sin la cual hubieran tenido dificultades de encaje y desarrollo para el desempeño de su actividad de forma eficiente». Como anteriormente se ha señalado, este equilibrio entre extrema competitividad y identidad cooperativa es difícilmente sostenible.

A continuación, analizaremos en qué medidas legislativas se nos muestra el peligroso proceso de "Privatización», por un lado expresado en su primera vertiente, la «Desnaturalización» y en última instancia, manifestado en la «Desmutualización» de la sociedad cooperativa. 
-PROCESO DE «DESNATURALIZACION». Los instrumentos SOcietarios de captación de capital, a saber, las figuras jurídicas que conceden derechos sociales propios de los cooperativistas a inversores ajenos a la actividad cooperativizada, son los siguientes:

1. Socio Colaborador: Se trata de una figura novedosa en la Ley estatal, que está llamada a sustituir al denominado Asociado, instrumento societario que tiene su origen en la Ley General de 1974. El artículo 14 de la Ley estatal lo define como «personas físicas o jurídicas que, sin poder desarrollar o participar en la actividad cooperativizada propia del objeto social de la cooperativa, pueden contribuir a su consecución». Remarcamos la importancia de que dicha clase de socio carezca de vinculación alguna con la actividad desarrollada por la entidad, ya que expresamente se cita su imposibilidad de participar en la misma. Además, tanto la participación máxima en el capital, como el poder de decisión de tales colaboradores en la Asamblea general ha aumentado sensiblemente con respecto a la anterior ley: el asociado podía llegar a ostentar el $33 \%$ del capital social (artículo 39 de la Ley $3 / 87$ ), participando en los órganos sociales con un conjunto de votos no superior al $20 \%$ de la totalidad de los existentes en la cooperativa (artículo 41) 29 . Por el contrario, el socio colaborador ve elevado su porcentaje en el capital social hasta un $45 \%$, pudiendo acumular una capacidad de voto del $30 \%$ (artículo 14). El legislador apuesta claramente por esta medida "societaria» de financiación cooperativa, abriendo la posibilidad de que se produzca un verdadero problema de «Descooperativización» de la misma.

Por su parte, la Ley Vasca de Cooperativas de 1982 introdujo por vez primera en su regulación autonómica la figura del socio colaborador, adaptándola en la posterior Ley 4/93. A diferencia de lo regulado por la normativa estatal, se permite la realización «parcial» del objeto social («aquellas personas físicas o jurídicas, que sin poder realizar plenamente el objeto social cooperativo, puedan colaborar en la consecución del mismo»), ampliando así la vinculación de esta figura con la cooperativa (artículo 19.2). Además, podrán ejercer el derecho de voto en los órganos societarios con un porcentaje superior al establecido por la Ley Estatal, a saber, el tercio de los votos como máximo; en

29 Alonso, Eva (1999), «Algunos comentarios sobre la nueva ley 27/99, de Cooperativas», Anuario de Estudios Cooperativos, Universidad de Deusto, Bilbao. 
el caso de que el socio colaborador sea una sociedad cooperativa, podrá participar en la vida societaria superando dicho límite, siendo el derecho de voto proporcional a la actividad cooperativizada con la sociedad (artículo 35.2). En cuanto al montante del capital social en manos de este tipo de socio, es expresamente excluido del límite total de un tercio al que deben someterse los demás socios ordinarios que no sean a su vez sociedades cooperativas (artículo 57.4). Con esta específica regulación se flexibiliza aún más el régimen dictado por la Ley 27/99, aumentando el porcentaje máximo de votos y suprimiendo el límite de participación en el capital social.

Cabe señalar el posible sentido del término «colaboración»: sin duda alguna, permite interpretar ampliamente la actividad ejercida por este socio en el ámbito cooperativo; se puede tratar perfectamente de una prestación personalista, de tal manera que no presentaría problema alguno a efectos de este trabajo.

No obstante, la finalidad con la que se ha constituido esta figura responde básicamente a la satisfacción de necesidades financieras de la sociedad cooperativa (colaboración financiera, por tanto), por lo que permite la concesión de derechos societarios a meros aportantes de capital. Así lo reconoce Emilio Olabarria, Director de Economía Social del Gobierno Vasco al tiempo de redactarse la Ley Vasca de Cooperativas de 1983: "Se encubre en las fórmulas específicas de socio colaborador al aportante de capital y al socio sin una vinculación efectiva a la actividad cooperativizada, siendo figuras de un carácter heterodoxo en la doctrina cooperativa, pero necesarias a efectos de consolidar una viabilidad financiera en ciertas cooperativas». Es más, la propia Exposición de Motivos de la Ley Vasca de Cooperativas de 1982 reconocía que la aportación primordial de esta clase de socio a la cooperativa era "fundamentalmente» la ayuda económica ${ }^{30}$, una ayuda, por cierto, de gran importancia para la expansión y promoción de sociedades cooperativas de trabajo asociado.

Con respecto a esta figura jurídica, señalamos su incuestionable validez para fortalecer la intercooperación en el seno de grupos cooperativos, ya que puede darse la posibilidad de que el capital aportado provenga de otra entidad cooperativa (una cooperativa de crédito, por ejemplo) y no de un mero inversor interesado únicamente en la

30 Zelaia UlíbarRI, Adrián (1995), op. cit, 125-135; Zelai Ulíbarri, Adrián (1992), op. cit., 199-213. 
rentabilidad de sus aportaciones: en este caso no se produciría la citada «Desnaturalización» de la cooperativa, sino que se acentuaría la aplicación del Principio de Cooperación entre Cooperativas.

Por último, cabe destacar la mayor flexibilidad con que dota la legislación vasca a esta figura con respecto a la Ley Estatal, aumentando tanto el límite de votos ejercitables como la participación en el capital social de esta clase de socios. En definitiva, se produce una cierta «desnaturalización» del sistema tradicional cooperativo.

2. Títulos Participativos: se trata de una figura de préstamo mercantil, configurada por vez primera en el ámbito estatal mediante la Ley 27/99, en el artículo 54.2 (este instrumento societario no estaba previsto en la anterior Ley General de 1987), aunque cabe decir que la Ley 4/93 de Cooperativas de Euskadi reguló con anterioridad Ley estatal las especificidades de estos títulos participativos (artículo 65.5). Las dos normas coinciden plenamente en la regulación dada al respecto, estableciendo dos características distintivas ${ }^{31}$ :

-El capital prestado posee una doble remuneración (remuneración mixta), un tipo de interés fijo y una parte variable determinada en función de la evolución de la actividad cooperativizada, es decir, de los resultados (únicamente se percibe cuando el excedente es positivo).

- A efectos de este trabajo nos interesa analizar la siguiente especificidad con que se dota a este instrumento jurídico: cabe la posibilidad de que los partícipes puedan ejercer el derecho de asistencia y voz, pero sin voto, en la Asamblea General. Nos encontramos ante la única nota diferenciadora con respecto a otras formas de captación de capital externo, como son los títulos participativos con las Obligaciones y las Participaciones Especiales. En definitiva, estos títulos se constituyen como «obligaciones con derecho de asistencia a la Asamblea general»32.

Destacamos la «posible» concesión de ciertos derechos sociales a terceros acreedores no socios, derechos que únicamente conllevan, como hemos señalado, la asistencia a la Asamble General con voz, pero sin voto: tanto en el artículo 65.5 de la Ley 4/93 de Cooperativas

31 Salaberría Amesti, Javier (1995), «El Régimen Económico-Financiero de las Cooperativas de trabajo Asociado», Federación de Cooperativas de Trabajo Asociado de Euskadi, páginas 78-79, Vitoria-Gasteiz.

32 Zelala UlíBARRI, Adrián (1995), op. cit., páginas 141-143. 
de Euskadi, como en la Ley estatal en su artículo 54.2, regulan «que el acuerdo de emisión podrá establecer el derecho de asistencia de sus titulares a la Asamblea General, con voz y sin voto». Unicamente cabe la posibilidad de que se confiera este derecho, por lo tanto no se establece obligatoriamente su otorgamiento. Pero en el caso de que efectivamente se permita a estos acreedores no socios asistir a las Asambleas con facultad de expresar sus necesidades e intereses, interpretaríamos esta concesión como una primer intento de aplicar la misma sistemática llevada a cabo por el legislador en el caso del socio colaborador: utilizar el otorgamiento de derechos sociales como instrumento facilitador de la captación de capital por parte de las sociedades cooperativas. Remarcamos que esta figura de financiación se puede conformar como "una primera aproximación societaria»33, es decir, como un primer paso hacia una mayor concesión de derechos políticos a «socios capitalistas» interesados únicamente en la rentabilidad de sus aportaciones. Denotamos una clara «Desnaturalización» de la esencia de la cooperativa, ya que, a pesar de no disponer del derecho de voto, la presencia de estos inversores en la Asamblea General puede ser sumamente influyente en la toma de decisiones de la cooperativa.

Esta evolución encaminada hacia una mayor permisividad del «capitalista» en la sociedad cooperativa, lejos de parecernos descabellada, se materializa en la regulación establecida en la Ley Catalana. En lo que respecta a este trabajo, tres son las diferencias con respecto a la legislación vasca y estatal que nos interesan dada su repercusión en la vida societaria de la entidad cooperativa:

—Artículo 60.4.1.b: se le confiere al partícipe «obligatoriamente» el derecho de asistencia a la Asamblea general; en la Ley vasca y en Ley Estatal, esta atribución es potestativa.

- Artículo 60.4.1.a: atribuye al acreedor externo el derecho a obtener la misma información «que cualquier socio de la cooperativa».

-Artículo 60.4.1.c: se abre la posibilidad a que los partícipes ostenten hasta tres representantes en el Consejo Rector, con voz y sin voto, sin superar el límite del $25 \%$ del total de miembros del mismo. Al igual que lo planteado en el caso de la asistencia de estos inversores en las Asambleas Generales, la presencia de los mismos en el Consejo Rector puede otorgarles un poder real sobre las decisiones de dicho órgano.

33 Zelala UlíbarRI, Adrián (1995), op. cit., página 145. 
A pesar de la limitación en el derecho de voto establecida para estos inversores, su potestad para asistir a las Asambles Generales (y en el caso catalán, para personarse en el Consejo Rector) es un importante paso hacia el incremento de concesiones «societarias» atribuidas a estos partícipes, destinadas a facilitar la captación de capital externo a la cooperativa; su influencia en las Asambleas Generales puede ser, además, decisiva, pagando así el alto precio de atenuar la identidad tradicional cooperativa.

3. Aportaciones capitalistas a las Cooperativas Mixtas: El artículo 107 de la Ley estatal de cooperativas y el artículo 136 de la Ley 4/93 de Cooperativas de Euskadi regulan, de idéntica manera, esta novedosa y peculiar figura jurídica. Se trata de un híbrido de sociedad (fórmula «intermedia» entre sociedad cooperativa y sociedad de capitales) en la que se establecen dos grupos diferenciados, uno plenamente cooperativista, y el otro constituido a modo de «célula capitalista», formado por "socios minoritarios cuyo derecho de voto en la Asamblea General se podrá determinar en función del capital aportado» (artículo 136.1 de la Ley vasca y artículo 107.1 de la Ley estatal). Dicho grupo minoritario, integrado por «socios capitalistas», podrá ostentar la cuota máxima del $49 \%$ de la totalidad de votos en la asamblea. Por lo tanto, al menos el $51 \%$ estará en manos de los cooperativistas (artículos 136.2 de la Ley vasca y 107.2 de la Ley estatal).

Los derechos y obligaciones de estos inversores van unidos a las denominadas partes sociales con voto, exactamente equiparables a las acciones capitalistas: éstas se regularán por los estatutos, con un régimen de posible circulación de las mismas, sometido a la legislación del mercado de valores; supletoriamente, se regularán en función de lo establecido por la Ley de Sociedades Anónimas.

La distribución de resultados estará sujeta a dos reglas de aplicación sucesiva: en primer lugar, habrá un primer reparto global, de manera que los dos grupos de socios participarán en los excedentes en función del porcentaje de votos de cada uno. En segundo lugar, los socios capitalistas percibirán los excedentes según el criterio capitalista tradicional (en función del capital desembolsado), mientras que los cooperativistas tendrán derecho al retorno proporcionalmente a su actividad cooperativizada.

Otro dato que debemos remarcar es la excepción que establece el legislador vasco a la norma general de irrepartibilidad de las reservas 
obligatorias, ya que dicha regla se atenúa sensiblemente en el caso de las cooperativas mixtas: en el momento de la configuración constitutiva de las mismas, o bien por modificación estatutaria, el consejo Superior de Cooperativas de Euskadi podrá autorizar la previsión estatutaria de repartibilidad del fondo de reserva obligatorio en caso de liquidación (artículo 136.5 de la Ley Vasca), aplicándose los criterios de distribución de los excedentes producidos por este tipo de cooperativas. Se exceptúa, por tanto, parte de la regulación ordinaria para la adjudicación del haber social. Aparece claramente reflejado el carácter híbrido de este tipo de sociedad cooperativa: los fondos de reserva obligatorios pueden ser apartados del destino originariamente fijado, a saber, la promoción y desarrollo del cooperativismo ${ }^{34}$.

La Cooperativa Mixta parece seguir el modelo de las sociedades laborales, con la salvedad de la no-negación de su carácter cooperativo en lo que al régimen organizacional y financiero del «subgrupo cooperativo» se refiere ${ }^{35}$. Por lo tanto, este tipo de sociedad cooperativa abandona su condición de proyecto autogestionado (propio del modelo cooperativo, en el que la totalidad de la empresa es de propiedad íntegra de los trabajadores) evolucionando hacia una concepción "cogestionada» (caso de las sociedades laborales, en las que el $50 \%$ del accionariado, como mínimo, se encuentra en manos de los trabajadores), retrocediendo en el logro de derechos societarios a favor de los trabajadores de la empresa ${ }^{36}$.

La figura de sociedad cooperativa mixta fue propuesta por MCC para subsanar el problema de la participación de sociedades de capitales en el seno de una sociedad cooperativa, cuando esta última se encuentre en una situación comprometida desde el punto de vista económico: se trata de impedir que, en caso de crisis financiera, una cooperativa se vea obligada a transformarse en una sociedad de capitales, pudiendo de esta manera mantener, aún de forma débil y atenuada, su identidad cooperativa ${ }^{37}$.

34 SAlAberRía AmeZtı, Javier (1995), páginas 92-93.

35 GAdEA, Enrique (1999), «Derecho de las Cooperativas. Análisis de la Ley 4/1993», de junio, de Cooperativas del País Vasco, páginas 279-281, Universidad de Deusto, Bilbao.

36 Divar, Javier (1983), «La Metamorfosis del capital. Bases de la empresa futura», Universidad de Deusto, Bilbao, páginas 49-53.

37 ZelalA UlíBARRI, Adrián «Estructura y problemática jurídica de la Corporación MCC», Anuario de Estudios Cooperativos, Universidad de Deuasto, 1992; SALAberría AMESTI, Javier (1995), op. cit., página 118. 
Por lo tanto, dicha figura está claramente destinada a facilitar el acceso de las cooperativas al mercado de capitales, atribuyendo a los inversores derechos societarios que refuerzan su dominio sobre la entidad. La sociedad cooperativa se adecua más bien a un modelo de empresa cogestionada, superando, incluso de forma amplia, la «desnaturalización» sufrida en el caso de socio colaborador. Cabe recalcar la posibilidad de que el voto de los socios cooperativistas se halle disperso o desunido, con lo que es factible el control de la entidad por parte de los socios capitalistas, a pesar de que no ostenten la mayoría de los votos asamblearios. En este caso, la cogestión evolucionaría (más bien se trata de una involución) a una fase de "cuasicogestión», constituyéndose un modelo de empresa dirigido fundamentalmente por socios capitalistas, alejándose aún más del proyecto autogestionado que es la cooperativa.

Por lo tanto, no cabe emplear de forma generalizada este instrumento para la captación de capital externo a la cooperativa, ya que de todas las formas de financiación existentes (manteniendo, eso sí, la forma jurídica cooperativa), ésta es, sin duda alguna, la más lesiva para el mantenimiento de las reglas tradicionales de funcionamiento interno cooperativo.

\section{-PROCESO DE DESMUTUALIZACION: Elementos facilitado- res de la "privatización total».}

Al definir el peligro de «Desmutualización», hemos señalado, de manera breve y abstracta, ciertos aspectos que facilitan enormemente la conversión de la sociedad cooperativa en una sociedad de capitales. A continuación determinaremos la existencia de estos «elementos facilitadores» en la legislación del Estado español.

1. Posibilidades de transformación de la sociedad cooperativa en una sociedad de capital: Tanto la Ley 27/99 de Cooperativas del Estado (artículo 69), como la Ley Vasca 4/93 (artículo 85) permiten la transformación de cooperativas en sociedades civiles y mercantiles de cualquier clase, si bien la Ley Vasca establece ciertos requisitos de obligado cumplimiento a la hora de realizar dicha conversión.

«La transformación sólo podrá efectuarse por necesidades empresariales que exijan soluciones societarias inviables en el sistema jurídico cooperativo, a juicio de los administradores $y$, en su caso, de la comisión de Vigilancia de la cooperativa, homologado por el Consejo Superior de Cooperativas de Euskadi» (artículo 85.1. apar- 
tado a de la Ley 4/93 de Cooperativas de Euskadi). Se trata, por tanto, de adoptar un régimen de funcionamiento diferente al de una sociedad cooperativa, ya que de no ser así, resultaría imposible para la empresa sobrevivir manteniendo el tipo de sociedad elegido inicialmente: el requisito esencial para la conversión es la concurrencia de circunstancias empresariales que hagan inviable la supervivencia de la empresa mientras se encuentre bajo la forma jurídica cooperativa. La decisión será tomada por el Consejo Rector y por la Comisión de Vigilancia, con la posterior homologación del consejo Superior de Cooperativas de Euskadi.

La Ley Estatal no fija ninguna condición de carácter empresarial, por lo que, en principio, cualquier sociedad cooperativa que lo desee puede realizar la transformación, siempre que cumpla con los requisitos estatutarios y legales establecidos para la fusión: la viabilidad o no de la empresa en la forma jurídica cooperativa es indiferente.

A tenor de lo señalado, es claramente factible la «Desmutualización» de la cooperativa, dado que la propia legislación permite la transformación de este tipo de empresa "en sociedades civiles y mercantiles de cualquier clase». En consecuencia, se posibilita a inversores titulares de derechos societarios proponer en la Asamblea General la conversión de la cooperativa y efectivamente, realizar dicha transformación en el caso de que ejerzan un dominio real sobre la empresa.

No obstante, debemos destacar el loable intento realizado por el legislador vasco a la hora de establecer límites a la conversión de la cooperativa en sociedades que de ninguna manera cumplen con los valores organizacionales propios del cooperativismo. Con esta específica regulación, se trata de describir la casuística relativa a una sociedad cooperativa necesitada de las aportaciones económicas de un inversor, cuando éste resulte reacio a adquirir la condición de socio colaborador o titular de las partes con voto de la cooperativa mixta ${ }^{38}$ (su deseo de ejercer un control objetivo en la empresa cooperativa es aplastante). Por lo tanto, si no se da la condición necesaria (que no suficiente) de la «extrema necesidad empresarial» de transformarse en sociedad no cooperativa para poder sobrevivir, al menos, como em-

38 Salaberría Amesti, Javier (1995), op. cit., página 118., Bilbao, 28 de noviembre. 
presa, los socios inversores no podrán, de ninguna manera, forzar dicha conversión valiéndose de su dominio real sobre la Asamblea General o Consejo Rector.

2. Repartibilidad de los fondos de reserva obligatorios en caso de transformación de la cooperativa en una sociedad de capitales: apropiarse de estas reservas puede ser el motivo por el que los socios cooperativos, socios inversores, $u$ otros capitales particulares externos a la empresa, vean atractiva la idea de consumar la conversión de la sociedad cooperativa en otra forma jurídica no-cooperativa.

La cuestión a debatir no es la repartibilidad o no de las reservas obligatorias durante la vida económica de la cooperativa: una parte de la doctrina, de carácter heterodoxa, se encuentra posicionada claramente a favor de la repartibilidad de esta clase de fondos ${ }^{39}$, fundamentando su opinión en el elevado beneficio que supondría la disponibilidad de estas reservas para el conjunto de socios de la cooperativa. Por lo tanto, dicha tendencia doctrinal en absoluto está destinada, a nuestro parecer, a facilitar la «Desmutualización» de la cooperativa.

El verdadero debate, a efectos de este trabajo, es la disponibilidad de estas reservas tras el proceso de transformación de la cooperativa en una sociedad de capitales, ya que la posible distribución de dichos fondos puede ser la causa de descooperativización de la entidad.

La Ley 27/99 de Cooperativas, en su artículo 69, impide, para el específico caso de la transformación de una cooperativa en una sociedad de otra naturaleza, la repartición entre los socios de los fondos de reserva obligatorios, del fondo de educación y de las reservas estatutariamente establecidas con este carácter de no disponibilidad. Con respecto al fondo de reserva obligatorio, la Ley señala en el artículo 75 que, tras cubrir las deudas sociales y demás destinos fijados para la adjudicación del haber social en caso de disolución, éste se «pondrá a disposición de la sociedad cooperativa o entidad federativa que figure

39 Rosembuj ERUJimovich, Tulio, "Los valores de la cultura económica del cooperativismo», Simposio sobre los valores de la cultura económica del cooperativismo vasco, Universidad de Deusto, Bilbao, 28 de noviembre de 2001. Inédito; GADEA, Enrique, «Tendencias Legislativas Internacionales», módulo integrado en el Curso de Especialización en Estudios Cooperativos, Universidad de Deusto, Bilbao, 29 de noviembre de 2001. 
expresamente recogida en los Estatutos o que se designe por acuerdo de Asamblea General. De no producirse designación, dicho importe se ingresará a la Confederación Estatal de Cooperativas de la clase correspondiente a la cooperativa en liquidación y de no existir la Confederación correspondiente, se destinará al tesoro público, con la finalidad de destinarlo a la constitución de un fondo para la promoción del cooperativismo».

La Ley 4/93 de Cooperativas de Euskadi determina que la Asamblea General que tome el acuerdo sobre la transformación, deberá atribuir al Consejo Superior de cooperativas de Euskadi la titularidad del valor nomimal del fondo de reserva obligatorio y de las reservas voluntarias irrepartibles, acreditándose como títulos de cuentas en participación referidos a la sociedad resultante del proceso transformador. Con respecto al fondo de educación y promoción cooperativa, la Ley Vasca lo destina a la cobertura de los fines estatutariamente previstos para dicho fondo y, en su defecto, establece su puesta a disposición por el Consejo Superior de Cooperativas de Euskadi (artículo 85).

En conclusión, cabe destacar el deseo del legislador de garantizar el destino cooperativo originario de los fondos irrepartibles, negando, también en el caso de la transformación, la libre disponibilidad de los mismos por parte de los socios. La causa de esta específica regulación se halla en la preocupación del legislador por evitar la «desmutualización» de la cooperativa, provocada con el propósito de distribuir individualmente entre los socios la totalidad de este tipo de reservas. Un dato reseñable, es la específica normativa que establece para este supuesto la Ley vasca, ya que matiza de cierta manera la irrepartibilidad de los fondos obligatorios: éstos no se destinan directamente a la confederación u órgano público correspondiente, sino que el valor de dichas reservas se acreditará como títulos de participación en la sociedad resultante, a nombre del consejo Superior de Cooperativas de Euskadi. Con esto, se pretende, además de evitar la descooperativización de dichos fondos, no sumar dificultades a la supervivencia de la nueva sociedad, utilizando esta «concesión» de las reservas como si de una fórmula de financiación complementaria se tratase. ${ }^{40}$

40 Salaberría Amesti, Javier (1995), op. cit., página 119. 
2.4. Conclusiones sobre la «Privatización» de las Sociedades Cooperativas: líneas generales de la Legislación Cooperativa Vasca y Estatal ante los peligros de «Desnaturalización» $y$ «Desmutualización»

Como ya hemos adelantado, adoptar una postura clara ante los procesos de «Desnaturalización» y «Desmutualización» es sumamente complicado. La respuesta más idealista al problema sería, sin llegar a dudas, adquirir al respecto un talante ortodoxo: mantener la estructura cerrada cooperativa, donde la financiación se apoya básicamente en la aportación de recursos por parte de los socios. Los valores cooperativos y las reglas tradicionales de funcionamiento inspiradas por los pioneros de Rochdale se alzarían totalmente íntegras dentro de un sistema en el cual la supremacía empresarial es ostentada por sociedades de capital.

No obstante, no debemos olvidar las limitaciones económicas de los socios a la hora de aportar capital a su propia empresa (la figura del cooperativista se encuentra directamente relacionada con la del trabajador de clase media, por lo que su capacidad de ahorro es ciertamente limitada) por lo que es necesario apoyar la estructura financiera de la entidad mediante la búsqueda de capital externo a la misma. Para ello, y como hemos apuntado anteriormente, una imagen de credibilidad hacia el exterior se hace imprescindible: ahí es donde entran en juego los instrumentos societarios de captación de capital, creándose paralelamente una cierta «desnaturalización» de la identidad cooperativa estricta. Nos encontramos ante fórmulas jurídicas de carácter heterodoxo, de naturaleza intermedia entre la sociedad cooperativa y la empresa capitalista, y no obstante, necesarias desde el punto de vista jurídico-económico: tal y como afirma Adrián Celaya Ulíbarri, «siempre ha sido una tentación del movimiento cooperativo intentar resolver sus problemas recurriendo a fórmulas menos cooperativas $\mathrm{O}$, si se prefiere, intermedias entre la cooperación y la empresa capitalista» ${ }^{41}$. A nuestro parecer, estas fórmulas, a pesar de ser un tanto lesivas para la identidad cooperativa, son también imprescindibles a la hora de garantizar la viabilidad de la empresa en un mercado extraordinariamente competitivo como el actual.

En conclusión, aunque la postura ortodoxa, con respecto a la esencia jurídica cooperativa tradicional, resulta sumamente romántica,

41 Zelala UlíBARRI, Adrián (1995), op. cit., página 140. 
nos vemos en la obligada situación de inclinar la balanza hacia el planteamiento esencialmente heterodoxo, eso sí, matizado en ciertos aspectos: a pesar de su indudable utilidad práctica, calificamos los instrumentos societarios de acceso al mercado de capitales como un mal menor, especialmente cuando el mal mayor es la inviabilidad empresarial de la cooperativa y su posterior disolución. Observamos que la tendencia adoptada por la legislación cooperativa, tanto estatal como autonómica, ha sido la creación de este tipo de formas de financiación que conceden a los inversores determinados derechos sociales, dañando en cierta medida la identidad cooperativa.

Por lo tanto, añadimos que los problemas financieros deben solucionarse mediante instrumentos estrictamente financieros (recurrir al crédito externo, contratos de cuentas en participación, obligaciones y bonos, etc.) tratando de excluir o, por lo menos, complementar en todo lo posible, las fórmulas jurídicas que concedan derechos societarios a personas no vinculadas a la cooperativa (o vinculadas únicamente con la inversión efectuada en la empresa). Remarcamos, no obstante, el interés que pueden suscitar las figuras societarias a la hora de complementar la labor realizada por los instrumentos estrictamente financieros; Además, es preciso insistir en la conveniencia de que los socios se involucren en el aspecto financiero de la cooperativa, tanto como sea posible; porque el que ellos confíen en la misma es una vía para atraer la atención de otros prestamistas ${ }^{42}$.

Otra vía de solución de los problemas financieros de la entidad cooperativa se encuentra en el desarrollo del asociacionismo cooperativo (en federaciones o confederaciones) y en la creación de grupos cooperativos (uniones de cooperativas formando agrupaciones empresariales o corporaciones cooperativas). Este tipo de estrategias, destinadas a mejorar el posicionamiento competitivo de la cooperativa, han sido apropiadamente utilizadas por las diferentes legislaciones, en especial por la legislación vasca, inspirada especialmente en este aspecto por MCC. Constatamos que es una forma modélica de preservación de los valores cooperativos tradicionales; señalamos que se trata, en concreto, de la aplicación práctica del valor de Solidaridad y del sexto principio cooperativo relativo a la cooperación entre cooperativas.

42 García Gutiérrez, Carlos, «La Rentabilidad Económico-Financiera de los socios», Jornadas Universitarias de Economía Social, Facultad de Ciencias Económicas y Empresariales de la UPV/EHU (Sarriko), Bilbao, 11, 12 y 13 de marzo de 2002. Inédito. 
En el caso de resultar inviable el modelo cooperativo aplicado a una determinada realidad empresarial, admitimos como válida la oportunidad ofrecida por las diferentes legislaciones de transformar una cooperativa en otro tipo de sociedad mercantil o civil. La finalidad de esta conversión es, sin duda, el mantenimiento de los puestos de trabajo, ya que de otro modo, la actividad empresarial dinamizadora de la sociedad y de la economía se vería abocada al fracaso (es decir, la liquidación). Si bien la Ley Estatal permite que dicha «desmutualización» se realice por causas diferentes a la mera supervivencia de la empresa, la legislación vasca deja resuelto este potencial peligro y en consecuencia, establece que tal conversión únicamente se producirá como última solución a la desaparición de la cooperativa.

La postura heterodoxa vuelve a imperar sobre otras tendencias más románticas pero, a la vez, menos realistas. No obstante, debemos aclarar que la Heterodoxia Cooperativa no es del todo contraria e incongruente con los valores del cooperativismo vasco: no olvidemos que este movimiento en especial «goza de un mayor realismo y aplica un menor dogmatismo o formalismo a su formulación ideológica y teórica». Arizmendiarrieta abogó por un idealismo práctico ${ }^{43}$, por el cual la persona (o la cooperativa) orientaba su conducta hacia la utopía, es decir, hacia un fin lejanamente posible e intrínsecamente bueno, de tal manera que los esfuerzos diarios eran destinados al logro de dicho fin. Arizmendiarrieta admite que las ideas sin actos que las realicen constituyen únicamente ideas: para realizar plenemente la utopía es necesario una actividad práctica frenética, eso sí, adecuada totalmente a la realidad y partiendo de ella. J. Divar ${ }^{44}$ afirma en este sentido que «todo cooperativismo implica una contestación reposada, realista, solidaria y altamente eficaz contra los abusos del capitalismo». Concebir la sociedad cooperativa sin esa obligada dosis de pragmatismo la desvirtúa, poniendo en peligro también la viabilidad del proyecto empresarial. Todo este planteamiento se materializa en el cuarto valor corporativo de MCC, Innovación, "Renovación Permanente», el cual establece en el plano empresarial "una actitud permanente de búsqueda de nuevas opciones en todos los ámbitos de actuación de las diferentes cooperativas, empujándolas en la experimentación de nuevas soluciones».

43 LANKI, Lankidetza Ikertegia (1999), op. cit, página 65.

44 Divar, Javier (1983), op. cit, página 53. 
Podemos concluir que la postura heterodoxa es característica inherente al cooperativismo, orientadora de su eficacia empresarial más intensa. No obstante, no por ser más realistas y pragmáticos debemos renunciar a los ideales o utopías cooperativas, ya que estos objetivos no son sueños ni quimeras, sino fines a los que se tiende obligatoriamente ${ }^{45}$. A continuación, analizaremos cómo la "actitud permanente de búsqueda de nuevas opciones» en el Grupo Eroski ha desembocado en un entramado empresarial, por lo menos, con respecto a las concepciones ortodoxas del cooperativismo.

\section{El modelo de expansión «No-Cooperativo» de Eroski S.coop: aplicación práctica del Principio de Refuerzo Empresarial}

\subsection{Introducción: la inviabilidad de las Sociedades de Capitales «Coo- perativizadas» como instrumento de captación de capital. Aproximación al modelo de expansión de Eroski S. Coop.}

La solución para evitar el peligros de «Desmutualización» se halla en la búsqueda de instrumentos jurídicos adecuados para que las cooperativas puedan competir en igualdad de condiciones frente a las actuales formas imperantes de organización empresarial, las sociedades de capitales.

Una vía para suplir las deficiencias de la estructura financiera cooperativa, cercana a la total "desmutualización», es la transformación de éstas en sociedades anónimas "cooperativizadas», como forma de acceder al mercado de acciones. En este caso, las participaciones accionariales de la nueva sociedad se redistribuyen en dos grupos: un grupo mayoritario es el integrado por los aportantes de trabajo; en el segundo grupo, se hallan los accionistas con carácter minoritario, o si su dispersión lo permite, propietarios de la mayor parte de la masa accionarial. Las Sociedades de Capitales «Cooperativizadas» que pretendan financiarse mediante la captación de acciones en el mercado de capitales, sufrirán una cierta «Desnaturalización» de su identidad «cooperativa». No obstante, seguirán manteniendo un reflejo atenuado del carácter personalista que en un principio ostentaron de forma ín-

45 Arizmendiarreta, José María (1983), «Pensamientos», Caja Laboral Popular, Mondragón. 
tegra. Su funcionamiento se asemejará a la organización interna de las Sociedades Laborales, no obstante, el «subgrupo cooperativo» puede adoptar una forma cooperativa en lo que a la administración de sus acciones se refiere: ello lo logra mediante el Sistema Dual Sociedad Cooperativa-Sociedad de Capitales, método que analizaremos a la hora de estudiar el caso de Gespa, S.C.P. Dicho instrumento de cooperativización se basa en la adquisición y administración del accionariado por parte de los trabajadores, mediante una sociedad diferenciada: los empleados no participan individualmente en la gestión de sus participaciones (como lo harían en el caso de las sociedades laborales), sino que lo hacen de forma colectiva, a través de una sociedad con organización interna independiente.

Este tipo de sociedad anónima "cooperativizada» posee los mismos inconvenientes para acceder al mercado de capitales que las sociedades laborales y sociedades cooperativas. En los tres casos, la retribución dada al factor trabajo, a costa de los resultados, es superior que la concedida al factor capital: todo ello, en perjuicio de la rentabilidad de la inversión efectuada por los accionistas no-trabajadores. Nuevamente, se produce la desconfianza del inversor en este tipo de empresa liderada, aun de forma difusa, por los aportantes de trabajo ${ }^{46}$.

En conclusión, cuando el mecanismo de «cooperativización» de una sociedad anónima y, en general, los mecanismos ideados por el derecho cooperativo carecen de validez o, simplemente, no son adecuados (bien por la peligrosa concesión de derechos societarios a estos socios «inversores», bien porque el montante logrado es insuficiente para financiar la actividad empresarial de la cooperativa), ha de buscarse un modelo de refuerzo empresarial que supla las carencias propias de las cooperativas: ha de tratarse de un modelo que permita acceder al mercado accionarial, sin los defectos expuestos para el caso de las sociedades anónimas «cooperativizadas» (es decir, sin que existan en estas entidades trabajadores-propietarios con una participación societaria mayoritaria).

Alicia Kaplan de Drimer, durante cierta reunión de la Asociación de Cooperativas Argentinas Ltda., propuso una alternativa a los instrumentos societarios de captación de capital: "Asociemos asimismo a las cooperativas de primer grado y a sus federaciones o asociaciones con personas de otro carácter jurídico, para constituir entidades o

46 ZelaiA UlíbARRI, Adrián (1995), op. cit., páginas 91-92. 
para realizar operaciones conjuntas, pero sin dejar que entren dentro de nuestras cooperativas aquéllos que no utilizan sus servicios y sólo protegen sus intereses financieros, sin importarles provocar la desaparición de las mismas porque, muchas veces, se proponen eliminar la competencia y monopolizar o bien oligopolizar diversos sectores de la economía». Remarca la necesidad de adquirir una dimensión empresarial idónea, pero sin permitir la utilización de instrumentos jurídicos societarios que concedan la entrada en la cooperativa a inversores, no vinculados con la actividad cooperativizada, con derecho de voto en los órganos sociales. Para ello, a nuestro parecer, propone la creación de alianzas con sociedades de diferente tipo (por ejemplo, sociedades anónimas), de tal manera que conjuntamente constituyan, entre otras opciones (ya que propone, además, otra clase de posibilidades menos «polémicas»), entidades no-cooperativas con las que poder realizar el citado proceso de expansión.

En conclusión: se preserva la estructura cerrada cooperativa, ya que el inversor no actúa directamente en el seno "societario» de la misma. No obstante, debemos preguntarnos si en verdad se garantiza la identidad cooperativa en esta clase de modelos de expansión nocooperativos: ¿no nos encontramos ante una clase distinta de «Desnaturalización» de la filosofía rochdaleana? Este proceso de pérdida de la identidad cooperativa se abordará mediante el análisis práctico del modelo de expansión de Eroski S.Coop.

\subsection{El modelo de expansión de Eroski S. Coop. Composición financie- ra e interpretación de su estructura societaria ${ }^{47}$}

Introducción histórica y especificidades de EROSKI S.COOP: Con el propósito de adoptar una dimensión regional, Eroski S.Coop fue creada en 1969 tras la fusión de diez cooperativas de consumo locales (Recalde de Bilbao, La Guerniquesa, La Marquinesa, La Zornoza-

47 Federación de Cooperativas de Euskadi (1994), Historia de las Cooperativas de Consumo Vascas, Vitoria-Gasteiz, páginas 125-134; Laura Gómez URQUIJo y Marta DE LOS Ríos AÑón (1197), «Respuestas a las dificultades de captación de capital en las Cooperativas: El Caso Eroski», Anuario de Estudios Cooperativos, Universidad de Deusto, Bilbao; CoopeRATIVA DE CONSUMO EROSKI (1994), 25 años de consumerismo, Elorrio, Bizkaia, páginas 15 y siguientes; EMPRESAS AvANZADAS EN GESTIÓN «Grupo Eroski. El crecimiento con calidad como filosofía de actuación; GÓMEZ URQUijo, Laura, "Análisis de Cooperativas Excelentes. Eroski», modelo integrado en el Curso de Especialización de Estudios Cooperativos, Universidad de Deusto; Visita realizada a la sede social de Eroski en Elorrio, organizada por el instituto de Estudios Cooperativos, Universisdad de Deusto. 
na, Ausuena de Matiena-Abadiño, La Ermuesa, Juan XXIII de Eibar, San José de Mondragón, Andra Mari de Aretxabaleta y San Andrés de Rentería), constituyéndose como un nuevo modelo de cooperativa de consumo: su especificidad se halla en la fijación de un determinado sistema de codecisión, en el que los órganos sociales están formados de manera paritaria, mitad consumidores y mitad trabajadores. De este modo, se logra integrar los intereses de los dos subgrupos en el proceso productivo. Además de la Asamblea General y el Consejo Rector (los cuales están formados en un $50 \%$ entre trabajadores y socios consumidores), existen órganos específicos para cada tipo de socio: el Consejo Social, en representación de los socios trabajadores, y el Consejo Consumerista, integrado por los socios consumidores.

La comunidad de socios trabajadores, además de poseer una indudable importancia en la estructura de la empresa, ostenta una elevada autonomía en la gestión de la administración ordinaria. Eroski, por su parte, al constituirse como una cooperativa de consumo, es en verdad una entidad privada de carácter popular que nace para defender los derechos de los consumidores, y proveerle de productos y servicios en las mejores condiciones.

A pesar de tan loables intenciones, el fin primordial de la cooperativa no deja de ser, como es lógico, la obtención del máximo beneficio en el mercado, siempre que la política de precios (fijada a su vez por el mercado) así lo permita. Históricamente, Eroski ha distribuido sus resultados de la siguiente manera: $50 \%$ de los excedentes se destinan al Fondo de Reserva Obligatorio, $10 \%$ al Fondo de Educación y Promoción Cooperativa (dirigido a la formación consumerista) y el $40 \%$ restante, que corresponde al retorno cooperativo, se capitaliza, reembolsándose al socio trabajador una vez haya abandonado la cooperativa.

Dos datos reseñables: primero, Eroski S.Coop, cuyo domicilo social se halla en Elorrio (Bizkaia), es parte integrante del entramado empresarial de Mondragón Corporación Cooperativa. Segundo, dado que su actividad comercial se desarrolla en las comunidades autónomas de Cantabria, Castilla y León, La Rioja, Navarra y País Vasco, Eroski queda sometido a la Ley 27/99, de Julio, de Cooperativas (la ley estatal), tal y como establece el artículo 1 de sus Estatutos Sociales.

Ciertamente, esta cooperativa de consumo se halla inmersa en un sector altamente competitivo, el sector de la distribución, donde se producen continuamente procesos de concentración empresarial, 
como fusiones, absorciones, participaciones en el capital de otras compañías con la finalidad de ejercer un control real sobre las mismas, etc. En 1997, el 40 \% de las ventas totales era facturado por tan sólo diez grupos empresariales (Eroski se posicionaba en tercer lugar); actualmente, el $48 \%$ del mercado está repartido entre cuatro grupos (Eroski es el segundo distribuidor con el 10,9\% de la ventas totales).

Un adecuado posicionamiento competitivo en el mercado pasa por lograr una dimensión empresarial adecuada: es necesario disponer de los recursos financieros suficientes que posibiliten dicha expansión, es decir, el acceso al mercado de capitales debe estar garantizado.

Tradicionalmente, Eroski S.Coop ha centrado su sistema financiero, casi exclusivamente, en las aportaciones realizadas por los socios trabajadores y consumeristas, de tal manera que no ha recurrido a instrumentos societarios de captación de capital externo. En este sentido, su estructura financiera se ha mantenido totalmente en consonancia con los requerimientos de la identidad cooperativa más estricta: no se ha producido en Eroski S.Coop ningún proceso «desnaturalizador», provocado, como ya se ha apuntado sobradamente a lo largo de este trabajo, por la intromisión en el seno de la cooperativa de inversores dotados de derechos sociales, únicamente interesados por la rentabilidad de sus aportaciones: por lo tanto, destacamos que el control societario reside íntegramente en manos de las dos comunidades de socios cooperativistas. No obstante, sí se utilizó la emisión de obligaciones como instrumento de captación de capital externo durante dos décadas, para dejar de ser utilizado en 1994. En el mismo orden de cosas, Eroski ha tratado de fortalecer sus mecanismos de autofinanciación mediante la posibilidad de suscripción, por parte de los socios, de aportaciones voluntarias retribuidas mediante un interés fijo anual.

Destacamos nuevamente que la estructura financiera de Eroski S.Coop se centra, casi exclusivamente, en las aportaciones efectuadas por sus socios trabajadores y consumeristas, manteniendo la cooperativa a salvo de injerencias o perturbaciones externas. No obstante, cimentar toda su capacidad generadora de recursos en la autofinanciación ha supuesto para Eroski un obstáculo a la hora de desarrollar un efectivo modelo de expansión, obligatoriamente exigido, en última instancia, por las especificidades del mercado en el que opera. 
Durante los años 1989 y 1990, se acentúa el fenómeno de concentración empresarial en el mercado europeo, liderado por las grandes firmas continentales de distribución (multinacionales con posiciones muy consolidadas en el mercado estatal), poniendo en grave peligro incluso la viabilidad empresarial de Eroski en la propia Comunidad Autónoma del País Vasco, ya que estas compañías comenzaban a desarrollar su actividad dentro de su entorno económico. Obtener la masa crítica, es decir, una mayor dimensión y expansión, aglutinando, cada vez, mayores cuota de mercado, es condición necesaria para sobrevivir empresarialmente en un sector como el de la distribución, altamente competitivo, superando su restringido ámbito de actuación autonómico y ampliándolo a escala estatal.

Composición Financiera del Grupo Eroski: La autofinanciación es insuficiente para encarar dicho proceso de expansión, por lo que EROSKI, tal y como había venido realizando históricamente, cimentó su estrategia en la política de alianzas entre cooperativas, creándose en 1990 junto a la valenciana cooperativa de consumo CONSUM (y al igual que Eroski S.Coop, también cooperativa de trabajo asociado) el «GRUPO EROSKI».

El Grupo Eroski se define en su misión como «una organización de distribución con un posicionamiento reconocido en la oferta de productos a un precio competitivo, que integra a los trabajadores en la gestión, que es progresista en la defensa de los derechos del consumidor y del medio ambiente y que es parte del entorno en el que opera». Los Valores del Grupo son los siguientes: "la importancia de los intereses colectivos sobre los individuales; el dinamismo y la capacidad de adaptación a los cambios como forma de asegurar la pervivencia futura; la necesidad de que todos los trabajadores participen y aporten a la consecución de los objetivos; el derecho y la obligación de todos los trabajadores de desarrollarse personal y profesionalmente como la mejor muestra de su profesionalidad; la importancia del equilibrio entre los intereses empresariales y personales; el compromiso social con el entorno; la orientación al cliente». En definitiva, el modelo de expansión del Grupo Eroski busca, junto a la consecución del beneficio, promover la transformación social.

En opinión de Constan Dacosta, presidente-director general del citado grupo empresarial, "el modelo cooperativo es difícilmente exportable a otras latitudes, por lo que se debió recurrir a otras fórmulas» para abordar la búsqueda de una mayor dimensión: hablamos de la 
utilización de sociedades de capitales como modelo más flexible de expansión. En 1991, Eroski y Consum, aglutinadas en el Grupo Eroski, crean CECOSA, Centro Comerciales, S.A.: una sociedad totalmente instrumental, constituida como sociedad matriz, destinada únicamente a la acumulación de recursos financieros provenientes de las dos cooperativas, estando formado el capital social de forma paritaria entre la entidad vasca y la valenciana; no desaparece flujo de caja del conjunto de las mismas. Su objeto será mantener una posición de dominio en la toma de decisiones de las sociedades donde se invierta este capital: nos referimos a las sociedades de capitales que materializarán la expansión del grupo.

La entidad capitalista en la que se invertirá íntegramente el capital cooperativo, se denominará EROSMER, S.A., sociedad nuevamente instrumental, es decir, constituida como sociedad de cartera destinada a la captación de capital externo a las dos cooperativas: de esta manera, junto a otras empresas de la economía social («socios financieros»), como ONCE, Argentaria, Lagun-Aro, BBK, las cooperativas de distribución italianas GDE y algunos socios externos de vinculación local, como las S.O.D.I., la Confederación Española de Cooperativas de Consumidores y Usuarios (HISPACOOP) y los directivos de las sociedades, CECOSA participará en el accionariado de los nuevos proyectos, materializados en grandes hipermercados, que el Grupo Eroski desarrollará fuera del ámbito originario de las cooperativas Eroski S.Coop (Comunidad Autónoma de Cantabria, Castilla y León, La Rioja, País Vasco y Navarra) Y Consum S.Coop (Comunidades Autónoma de Cataluña, Murcia y Valencia).

A partir de 1996, la sociedad de cartera EROSMER, en la que el Grupo Eroski ostenta la mayoría del capital social mediante CECOSA, abastece de recursos financieros a la una nueva sociedad denominada EROSMER IBERICA, S.A., encargada directa de la creación y posterior desarrollo de los proyectos comerciales del GRUPO EROSKI en las áreas no-cooperativas, es decir, territorios en los que Eroski S.Coop y Consumer S.Coop no realizan actividad alguna mediante figuras estrictamente cooperativas.

El Grupo Eroski se ha valido nuevamente de CECOSA para llevar a cabo la adquisición de ciertas entidades competidoras, con el fin de aglutinar una cuotas cada vez mayores de mercado y posicionarse definitivamente en el sector de la distribución: así compra CENCO, JOBAC y BALIAK. 
Por otro lado, el Grupo Eroski, mediante su sociedad instrumental CECOSA, ha protagonizado nuevamente otras alianzas con el objeto de proyectar su actividad comercial, tanto al resto de Estado español, como al exterior, en concreto, al sur de Francia: junto con la cooperativa francesa ADOUR PYRENÉES crea ALTIS (sociedad de cartera, al igual que CECOSA) para la expansión en el Estado francés, ostentado cada una la mitad del capital social; esta nueva explotación se realizó a través de una sociedad de desarrollo denominada SOFIDES, con funciones idénticas a las que desempeña EROSMER IBERICA en el Estado español. De igual modo, se han desarrollado alianzas con MERCAT materializadas en la empresa UDAMA, participando nuevamente CECOSA en el $50 \%$ del capital social; con UNIDE (Castilla León, CastiIla La Mancha, Extremadura, Valencia, Murcia y Canarias) constituye la empresa SUPERA, participando en la mitad del capital; con VEGONSA crea la empresa VEGALSA, participando también con el $50 \%$ del capital social ${ }^{48}$.

Interpretación del modelo de expansión de Eroski S.Coop: Hemos destacado la relevancia de la originaria estructura financiera de Eroski, con respecto a la concepción tradicional del cooperativismo: una empresa de eficiencia punta financiada íntegramente mediante las aportaciones de sus socios cooperativistas. A la luz de los valores y normas de funcionamiento rochdaleanas, Eroski constituye el perfecto modelo (o casi perfecto, ya que la perfección plena cooperativa no existe en un modelo socio-económico capitalista) de entidad cooperativa, en la que la totalidad del poder político es ejercido por sus socios: en esencia, una empresa fundamentada en la autoayuda, en la autorresponsabilidad, cimentada en la equidad (a cada trabajador o consumidor, los frutos verdaderos de su propio trabajo, el verdadero sustento de la empresa), informada por el valor de «democracia económica», el cual propicia el paso de los trabajadores (y también de los consumidores) a la condición de propietarios del centro de producción, y por último, pero no menos importante, inspirada por la solidaridad, entendida tanto entre personas de la misma cooperativa, como también referida al entorno económico-social de la empresa. En este tipo de cooperativa, la gestión democrática por parte de los socios

48 Federación de Cooperativas de Consumo de Euskadi (1994), op. cit., páginas 131-134; Laura Gomez Urquijo y Marta de los Ríos Añón (1997), op. cit.; Visita realizada por los alumnos del Curso de Especialización de Estudios Cooperativos de la Universidad de Deusto a la sede de Eroski S. Coop., en Elorrio, el día 18 de abril de 2002. 
está garantizada mediante la autonomía e independencia de la empresa con respecto a las posibles injerencias de inversores externos en el seno de la misma. Además, tratándose de una cooperativa de consumo, el interés por la comunidad se refleja plenamente gracias a la adhesión libre de los consumidores al proyecto cooperativo autogestionado.

No obstante, este "Núcleo Cooperativo» se ve puesto en peligro por la obligación de «crecer para simplemente sobrevivir»: la práctica desarrollada por Eroski, centrada en la autofinanciación, es inviable, ya que los recursos necesarios para llevar a cabo la expansión son insuficientes. Una opción consiste es recurrir al crédito o a inversores externos a la cooperativa. En definitiva, acceder al mercado de capitales, con la dificultad "cooperativa» de falta de credibilidad con respecto a los citados capitalistas externos (dificultad ya analizada en el punto segundo del presente trabajo). Lograr esa capacidad de crédito supone, muchas veces, «desnaturalizar» la esencia cooperativa.

Pues bien, Eroski S.Coop no accedió a transgredir el «Núcleo Cooperativo», optó por desarrollar un modelo de expansión ajeno al cooperativo mediante una compleja política de alianzas. En palabras de Constan Dacosta, «la elección entre el crecimiento necesario de la entidad madre (EROSKI) y el hacerlo a través de un modo ajeno al cooperativo, no ha sido fácil, pero ha prevalecido el PRINCIPIO DE REFUERZO EMPRESARIAL ${ }^{49}$ ». Eroski garantizó, de esta manera, la salvaguarda de su identidad cooperativa, ya que, de apostar únicamente por el crecimiento de la sociedad matriz, ésta sufriría la «desnaturalización» provocada por el casi obligatorio acceso al mercado de capitales mediante instrumentos societarios: es decir, mediante la figura de socio colaborador, la conversión en cooperativa mixta o en sociedad anónima "cooperativizada». Como es lógico, el sistema utilizado para expandirse fue el capitalista. La naturaleza jurídica de las sociedades anónimas permitía contar con la suficiente flexibilidad para desarrollarse económicamente: el inversor capitalista no sufre la limitación establecida en la cooperativa para los meros aportantes de capital, restricción relativa a la capacidad de ejercer derechos sociales; en la sociedad anónima, el capitalista puede efectivamente ejercer los derechos sociales, ya que él mismo es propietario de la empresa donde realiza la inversión. Su control sobre la rentabilidad de sus aportacio-

49 DAcosta, Constan (1991), op. cit. 
nes puede ser definitivo en el caso de poseer la mayoría del capital: la credibilidad de la empresa con respecto a los capitalistas es máxima.

Hubo otra razón que propició la adopción del modelo de expansión no cooperativo: la falta de noción del «significado de empresa cooperativa» por parte de las poblaciones afectadas por dicha expansión. En verdad, la carencia de una arraigada cultura cooperativa en dichas regiones supuso también, en opinión de los implicados en dicha elección, inclinar la balanza hacia un modelo capitalista: según Constan Dacosta, el modelo cooperativo es, en la actualidad, difícilmente exportable a otras latitudes. En nuestra opinión, es inadmisible la idea de que los trabajadores (y los consumidores o usuarios) de una región sin experiencia cooperativa previa, sean incapaces de adaptarse a la cultura cooperativa, ya que las necesidades centradas en la democracia económica son universales y comunes a todos los pueblos. Sí es cierto, que el hecho de utilizar un instrumento jurídico de captación de capital que no sea tradicionalmente conocido en el mercado, vulnera ampliamente su eficacia: existen en el mercado de capitales ciertos hábitos que no deben olvidarse, por lo que si el derecho cooperativo utiliza figuras jurídicas no habituales en dicho mercado, el inversor desconfiará de tales modalidades financieras ${ }^{50}$.

Todas estas razones podrían justificar la utilización de un modelo de expansión ajeno al cooperativo. No obstante, remarcamos la defensa que del "Núcleo Cooperativo» realiza Eroski. Su alianza con Consum S.Coop (creando el GRUPO EROSKI) se materializa en la sociedad anónima CECOSA, en la que el capital social está formado paritariamente por las dos cooperativas. Todo este flujo de tesorería, junto al capital de otros socios financieros, se invierte en EROSMER, S.A.: el Grupo Eroski participa en dicho capital de forma mayoritaria, por lo que controla íntegramente la sociedad. El proyecto de expansión se materializa en última instancia en EROSMER IBERICA, S.A., la sociedad de capitales responsable directa de la puesta en marcha de los establecimientos: el capital social mayoritario reside nuevamente en el GRUPO EROSKI, por lo tanto, también el control casi total (por lo menos, mayoritario) de todo el entramado societario del modelo expansión. En conclusión: el entorno cooperativo, es decir, lo que hemos denominado el «Núcleo Cooperativo» (estrictamente, las sociedades cooperativas EROSKI y CONSUM) se mantiene intacto de cualquier injerencia capitalista, evitándose el proceso «desnaturalizador» referido

50 Zelaia UlíbarRI, Adrián (1995), op. cit. 
en exclusiva al área interna de las dos cooperativas. Los socios inversores únicamente actúan en las sociedades de capitales, no en el seno de las cooperativas.

Como afirma J.Divar ${ }^{51}$, con respecto a la solidaridad social, «debe también entenderse que las prestaciones sociales empresariales (como células productivas de la comunidad) no tienen sólo un área interna, sino además otra externa y general». Aplicado este principio al entramado societario del GRUPO EROSKI, observamos que es, en esencia, insolidario, aunque a continuación matizaremos esta insolidaridad con el modelo GESPA, S.C.P. de participación de los trabajadores de EROSMER IBERICA en la gestión de esta sociedad de capitales. Si bien el «Núcleo Cooperativo» se encuentra «protegido» (manteniéndose informado en su funcionamiento interno por la identidad cooperativa), el resto de sociedades integradoras de la composición financiera del grupo se inspiran en puros valores capitalistas: la rentabilidad es el fin último tanto de CECOSA como de sus socios financieros, y no la satisfacción de necesidades de los usuarios (como es la tendencia obligatoria en cualquier cooperativa).

Destacamos, por lo tanto, que el objeto de este proceso de crecimiento y refuerzo empresarial es la preservación de la viabilidad económica del «Núcleo Cooperativo»: "Es necesario crecer para sobrevivir», y eso es, precisamente, lo que ha impulsado esta expansión. No obstante, nos es imposible determinar la desviación del modelo societario del GRUPO EROSKI, con respecto a los valores del cooperativismo, y en consecuencia, calificarla de insolidaria, sin antes analizar el efecto real en EROSMER IBERICA, S.A. de la sociedad civil particular GESPA.

3.3. GESPA, S.C.P., Gestión de Participaciones: Alcance real de su efecto «cooperativizador» en Erosmer Ibérica, S.A.

Introducción: la "cooperativización» de las sociedades de capitales $^{52}$. Efectivamente, existen ciertos mecanismos jurídicos que posibilitan la modificación de la naturaleza «privada» de la empresa capitalista, acercando su estructura societaria a la de las sociedades cooperativas. En este tipo sociedades, la soberanía o poder social se

51 DIvAR, Javier (1993), op. cit., página 78.

52 ZelaiA UlíbARRI, Adrián, (1995), op. cit., páginas 151-155. 
distribuye en función del capital aportado por los inversores: por lo tanto, el derecho de voto ejercitable en los distintos órganos societarios es directamente proporcional al número de acciones o participaciones en el capital social de la empresa. Pues bien, los instrumentos «cooperativizadores» redistribuyen el poder social, depositándolo en manos de los trabajadores y convirtiendo la empresa capitalista en una sociedad de naturaleza personalista (aproximación a las sociedades cooperativas) o laboral (conversión en sociedad laboral).

Encontramos diversos tipos de instrumentos para llevar a cabo esta cooperativización de la sociedad de capitales: ofrecimiento directo a los trabajadores de parte de la masa accionarial de la empresa (accionariado obrero), fijación por vía legal o estatutaria de una cantidad mínima de capital social en manos de los trabajadores (el caso de las sociedades laborales), etc.

A efectos del análisis del modelo de participación de GESPA, nos interesa estudiar los denominados Planes de Adquisición de Capital por los Empleados o ESOP (Employee Stock Ownership Plans), ya que, en nuestra opinión, muestran una gran similitud con el citado mecanismo de participación de los trabajadores de EROSMER IBERICA. Dicho instrumento de cooperativización, desarrollado en el ámbito de los países anglosajones (impulsado tanto por los gobiernos, como por los sindicatos) se basa en la adquisición y administración del accionariado por parte de los trabajadores, mediante una sociedad diferenciada. Por lo tanto, los empleados no participan individualmente en la gestión de sus participaciones (como lo harían en el caso de las sociedades laborales), sino que lo hacen de forma colectiva, a través de una sociedad con organización interna independiente: esta nueva entidad, destinada únicamente a ejercitar los derechos sociales correspondientes a las acciones, poseerá libertad plena para constituirse con la forma jurídica que determinen sus socios. Así, podrá ser tanto una cooperativa (como ocurre en el SISTEMA DUAL sociedad de capitalessociedad cooperativa), como una sociedad anónima o una sociedad civil particular (es el caso de GESPA, S.C.P.).

Existen diferentes tipos de ESOP, en función del grado de participación de los trabajadores en el capital social de la empresa: puede ser una participación mayoritaria, de tal manera que el control de la sociedad se encuentre efectivamente en manos de los empleados, o bien minoritaria. Otra clasificación consistiría en diferenciar los citados planes de adquisición de acciones según el modo de ejercitar el dere- 
cho de voto en la entidad diferenciada: distribuyendo el derecho de voto en función del capital aportado por cada trabajador («Conventional ESOP»), o bien ejercitando dicho derecho de forma cooperativa, «una persona, un voto» («Democrátic ESOP»).

Estos mecanismos desarrollan un efecto "cooperativizador» más profundo que el realizado por las sociedades laborales $u$ otros instrumentos de naturaleza similar, ya que los derechos societarios correspondientes a las acciones en poder de los empleados son ejercidos de forma conjunta mediante la entidad diferenciada, concentrando las decisiones (es decir, concentrando el poder social) y aumentando el control efectivo sobre la empresa por parte de los trabajadores. En nuestra opinión, el caso de GESPA es equiparable al citado proceso de cooperativización de sociedades de capitales mediante las ESOP, y se encuentra estrechamente relacionado con la estructura dual sociedad de capitales-sociedad cooperativa.

Estructura societaria y funcionamiento de GESPA, Gestión de participaciones, S.C.P. «Evidentemente, ni los trabajadores ni los consumidores serán socios en tales proyectos, aunque se perseguirá trasladar a los mismos algunos de los elementos de la gestión y participación de Eroski que no exigen la condición societaria para su implantación». Tal y como señala Constan Dacosta, Eroski ha pretendido realizar un esfuerzo "cooperativizador» en el seno de EROSMER IBERICA, S.A. mediante la creación de una sociedad civil particular denominada GESPA, Gestión de Participaciones, destinada a adquirir y administrar las acciones o participaciones sociales de EROSMER IBERICA que se encuentren en poder de los trabajadores de la misma. Por lo tanto, el esquema analizado en el punto inmediatamente anterior, referido al SISTEMA DUAL y a las ESOP, vuelve a repetirse en este proceso que, según el presidente-director general del Grupo Eroski, está «basado en la filosofía de las cooperativas de consumo Eroski y Consum»: la adquisición y administración del accionariado por parte de los trabajadores, mediante una sociedad diferenciada, por lo que los empleados no participan individualmente en la gestión de sus participaciones, sino que lo hacen de forma colectiva, a través de una sociedad con organización interna independiente.

Para la constitución de dicha entidad diferenciada se optó por la forma jurídica de la sociedad civil particular debido a la gran libertad que esta figura ofrece para la fijación de relaciones, pactos y acuerdos entre quienes la componen: se trata de un contrato civil por el que 
dos o más personas se obligan a poner en común dinero, bienes o industria, con ánimo de repartir entre sí las ganancias. Los socios se reúnen y toman acuerdos según las necesidades de cada momento: no hay un órgano específico de gobierno, por lo que las personas integrantes de la sociedad civil pueden crear la estructura societaria más conveniente para la consecución de sus fines. Por lo tanto, los estatutos de dicha forma jurídica puede mantener una gran similitud con los de una sociedad cooperativa, y en especial con los estatutos sociales de las cooperativas del GRUPO EROSKI, permitiendo una participación voluntaria de los trabajadores de la sociedad anónima y unas aportaciones económicas más reducidas que las de los socios cooperativistas.

El artículo 2 de los estatutos sociales fija el fin último de GESPA: «El objeto social lo constituirá la adquisición, tenencia y administración de acciones o participaciones sociales de la empresa en la cual prestan sus servicios como trabajadores por cuenta ajena los socios Gestión de Participaciones, S.C.P. (Gespa). Asimismo, constituye objeto de la sociedad la participación en la gestión y administración de aquella empresa o empresas en las que sea partícipe Gespa, realizada a través de los órganos e instancias formalmente constituidos. Sin perjuicio del objeto social antes mencionado, la finalidad que los socios persiguen con la constitución de esta sociedad consiste en la participación de los mismos en la propiedad y gestión de la empresa donde trabajan en régimen de contrato laboral indefinido $y$, desde esa posición, promover y defender los legítimos intereses de los consumidores, fomentar la creación de puestos de trabajo y propiciar el desarrollo personal y profesional de los trabajadores». En definitiva, los socios de GESPA se unen para adquirir y administrar las acciones o participaciones sociales (suma de las aportaciones obligatorias más los retornos y las aportaciones voluntarias de los socios) que la propia sociedad oferta, y por lo tanto, participan en la propiedad y gestión de la empresa donde trabajan. A nuestro parecer, y lo remarcamos nuevamente, existe una notable similitud entre este sistema de participación de los trabajadores y las ESOP y el denominado SISTEMA DUAL sociedad de capitales-sociedad cooperativa.

GESPA está compuesta por dos tipos de socios: los trabajadores individuales de EROSMER, S.A. (denominados de clase A) y Centros Comerciales CECOSA, mediante la cual se encuentran representados los socios cooperativistas de Eroski, S.Coop y Consum, S.Coop (socios de clase B). 
Los socios de clase A son aquellos que tienen contrato laboral indefinido en cualquiera de las empresas participadas por GESPA: por lo tanto, la condición de socio de dicha clase está directamente ligada a la condición de trabajador; si un socio causa baja laboral voluntariamente en la empresa EROSMER IBERICA, o incurre en alguna causa de despido laboral, automáticamente deja de ser socio de la sociedad civil particular. Para poder ser admitido, además de cumplir con la condición de ser trabajador de EROSMER IBERICA y superar el período de prueba que se haya fijado en el contrato, se deberá realizar la aportación fijada al capital social y aceptar el contenido de los Estatutos y reglamentos por los que se rige GESPA: al igual que en la filosofía cooperativa, nadie puede ser excluido por sus ideas políticas o sindicales, ni por sus creencias religiosas ni por su nacionalidad, sexo, raza o estado civil.

La admisión del socio se realiza de siguiente manera: reunidos los anteriores requisitos la dirección de EROSMER IBERICA presenta un informe al Consejo Rector de Gespa y éste decide sobre la aptitud del solicitante. Se da por supuesto que los socios de clase B, representados por CECOSA, son parte de la sociedad particular desde la constitución de la misma, ya que su admisión en GESPA no se realiza de manera individualizada, sino en bloque: es CECOSA la que se introduce íntegramente en el seno de la sociedad civil, sin ninguna clase de requisito previo (únicamente la aportación de capital).

La intención de trasladar algunos de los elementos propios del cooperativismo se nos muestra en el artículo 10 de los estatutos, relativo a las obligaciones de los socios: «el socio está obligado a asistir a los actos sociales y juntas, acatando los acuerdos aprobados; contribuir a un adecuado clima social y a una respetuosa convivencia en las relaciones tanto con los cargos directivos como con los demás socios; no manifestarse públicamente en contra de la sociedad; Participar en las actividades de formación que se promuevan desde GESPA o EROSMER IBERICA; no desarrollar actividades contrarias a las leyes o en competencia con las empresas participadas por GESPA». En cuanto a sus derechos como socios, tienen derecho a elegir y ser elegidos para los cargos sociales de la sociedad; derecho a formular propuestas y participar con voz y voto en los órganos sociales; recibir la información necesaria para el ejercicio de sus derechos; definir en asamblea general la política, objetivos, medios y ámbito de la actividad societaria; al reparto de beneficios, aprobados por la asamblea general; participar 
en las actividades y servicios que organice la Sociedad; acudir a los órganos societarios de representación en la forma y plazos establecidos.

El capital social es de naturaleza variable y mantendrá la proporción aproximada del $50 \%$ para los socios de clase A y del restante $50 \%$ para CECOSA. Cada trabajador socio realiza una aportación obligatoria de unos 3.000 euros. La aportación efectuada por los socios que se integraron en GESPA entre 1997 y 1998 se contabilizará en su totalidad como participación social. A partir de 1999, los nuevos socios realizan una aportación adicional denominada capital cedido, no retornable: corresponde al incremento de valor de GESPA durante ese año, es decir, 3.000 euros + I.P.C. + $8 \%$. Además, el Consejo Rector puede acordar la realización de aportaciones voluntarias.

El valor patrimonial de Gespa se incrementa si aumenta el capital social debido a la entrada de más socios (pertenecientes a la clase A), o bien si los resultados del ejercicio son positivos, aumentando el valor de las acciones en manos de los trabajadores. En este último caso, el Consejo Rector puede emitir nuevas acciones, denominadas acciones liberadas, y donarlas gratuitamente a los socios de clase A, aumentando así su participación en el capital social de Gespa. Como ya hemos adelantado, cada socio es propietario de participaciones sociales, pero únicamente podrán disponer de ellas cuando causen baja en Gespa. No obstante, si existen dividendos, cada socio podrá disponer anualmente de aquéllos que se correspondan con su participación social.

La gestión de GESPA se lleva cabo a través de la Asamblea General y el Consejo Rector. La Asamblea General, órgano supremo de expresión de la sociedad está compuesta por 400 delegados, elegidos a partes iguales por los socios de clase A y B de CECOSA. Lo centros de trabajo que superen los 80 trabajadores socios de GESPA constituirán anualmente una reunión denominada Junta Preparatoria, donde los socio de clase A personalmente eligen a los delegados que los representarán en la Asamblea General.

Dicha asamblea, tanto ordinaria como extraordinaria, es competente en las siguientes cuestiones: designa y cesa a los miembros del Consejo Rector; examina la gestión social, aprueba las Cuentas y la distribución de beneficios o imputación de pérdidas; acuerda nuevas aportaciones obligatorias, la actualización del capital inicial o del capital cedido para nuevos socios; emite obligaciones; establece la política general de la sociedad y conoce la de EROSMER IBERICA; modifi- 
ca los estatutos sociales, aprueba y varía el reglamento interno de la sociedad; acuerda la fusión, escisión o disolución de la sociedad; controla las actividades del Consejo Rector y la de la dirección de la empresa. La Asamblea General la preside y dirige el presidente del Consejo Rector y si éste no está, el Vicepresidente. Los delegados de las diferentes clases de socios tienen un voto simple cada uno y pueden además ostentar la representación de un voto delegado: los acuerdos se adoptan por mayoría simple.

El Consejo Rector, órgano de gobierno, gestión y representación, está compuesto por doce miembros elegidos paritariamente por los socios de clase A y CECOSA: los miembros representantes de la clase A son elegidos entre lo socios en votación secreta, en la Asamblea General; El Presidente del Consejo es elegido entre los socios de la clase $B$ y el Vicepresidente, entre los socios de la clase A. El Consejo Rector se reúne una vez al mes en sesión ordinaria, acudiendo a la misma el Director General y el Director de Recursos Humanos de EROSMER IBERICA: los acuerdos son tomados por mayoría simple.

Según el artículo 40 de los estatutos, es «la de procurar la mejor gestión de las empresas participadas en la medida en que ello supone repercusiones económicas y sociales sobre los trabajadores-socios. Por tanto, será su orientación principal colaborar en la gestión de las empresas participadas en su vertiente empresarial y social, más que la mera optimización económica de los recursos de la sociedad». De esta manera las competencias de mayor relevancia de dicho órgano son las siguientes: organiza, dirige e inspecciona la marcha de la sociedad y propone a la Asamblea General el Reglamento de régimen Interno Social; la opinión que da sobre el nombramiento de los equipos directivos de EROSMER IBERICA y gerentes de los centros de trabajo es tenida «muy» en cuenta; propone al Consejo de Administración el plan de gestión de la empresa; determina la inversión concreta de los fondos disponibles y los presupuestos, respetándolos acuerdos de la Asamblea General; presenta anualmente a la Asamblea General las cuentas, balance y memoria explicativa de la gestión del Consejo Rector y propone la distribución de los excedentes netos; convoca las asambleas generales ordinarias y extraordinarias; acordar la admisión y cese de socios; informa a los socios trabajadores de la evolución económica de EROSMER IBERICA.; el presidente del Consejo Rector, perteneciente a CECOSA, es también el presidente de GESPA. 
Destacamos que GESPA posee más poder de decisión sobre EROSMER IBERICA que lo que su participación económica en dicha sociedad le confiere: es competencia de la sociedad civil particular acordar el despido laboral de un trabajador socio, por lo que la dirección de Erosmer lbérica es incapaz de despedir a un trabajador socio de Gespa sin la previa autorización de la misma. Esta capacidad de decisión no presentaría consecuencia jurídica alguna si no es porque el contenido de los estatutos relativos a dicho aspecto ha sido integrado en el sistema de gestión de Erosmer lbérica, mediante el reconocimiento de CECOSA (socio mayoritario de EROSMER, y a la vez de EROSMER IBERICA) en documento público, de su limitación a la hora de proceder al despido de cualquier trabajador socio de Gespa.

Con la finalidad de fomentar la participación de los trabajadores en la vida societaria, de manera que ésta no se limite únicamente a la Asamblea General, el artículo 44 de los estatutos establece la creación del Consejo Social, figura inexistente en el derecho comparado y perteneciente a la formación ideológica del cooperativismo vasco, tal y como señala la Exposición de Motivos de la Ley 4/93 de junio, de Cooperativas de Euskadi («reconociéndose de esta manera una rica experiencia desarrollada históricamente en las cooperativas de nuestra comunidad», referencia implícita a la práctica llevada a cabo por las cooperativas de Mondragón): «los consejos sociales, órganos delegados del Consejo Rector, nacen para un mejor funcionamiento societario y para procurar la participación e integración de los socios. Para ello, como principio general se establece que en las empresas participadas por Gespa, que dispongan de centros de trabajo en los que se superen los 80 socios trabajadores, se constituirá un consejo social por cada centro de trabajo. La misión de cada consejo social es procurar la mejor gestión de los centros de trabajo, para lo cual deberá recabar información y opinión de los socios y canalizarlas al Consejo Rector, al tiempo que se ocupará de transmitir y comunicar los aspectos generales relativos a la vida societaria y empresarial del Grupo Eroski».

Cada consejo social está compuesto por 12 miembros, de los cuales 4 son miembros natos: el gerente del centro, el jefe del personal, el presidente del Comité de empresa (en el caso de que fuera socio, de lo contrario, asistiría a las reuniones, con voz y sin voto) y un miembro del consejo rector.

Las competencias más importantes de este órgano son las siguientes: posibilidad de «opinar» mediante informe sobre la propuesta de 
despido de un socio; debate y analiza las propuestas del Comité de Empresa relativas a su centro; emite informe previo al Consejo Rector para resolver recursos internos sobre las propuestas de falta y sanciones de carácter social, por la dirección del centro; supervisa la gestión económica, comercial y societaria del centro; control y enjuiciamiento de la configuración del plan de gestión anual y cumplimiento del mismo, etc.

Señalamos el gran éxito de participación obtenido por Gespa desde su creación en 1998, ya que en la actualidad, el $90 \%$ de los empleados de Erosmer Ibérica forman parte activa de dicha sociedad: este dato nos muestra el esfuerzo efectuado por el Grupo Eroski de trasladar su modelo de gestión cooperativo al entorno de las sociedades anónimas.

Alcance real del efecto "cooperativizador» de GESPA, S.C.P. Uno de los mayores obstáculos para desempeñar con éxito este proyecto de "cooperativización» de una sociedad capitalista, es sin duda, el carácter minoritario de la masa accionarial detentada por los empleados con respecto a los demás inversores: la aportación inicial y obligatoria necesaria para acceder a ser socio de Gespa (3.000 euros) es sensiblemente inferior a la cantidad establecida para la admisión de un cooperativista del grupo en su respectiva entidad: por lo tanto, la capacidad de autofinanciación de Gespa es menor que la de cualquier cooperativa del citado grupo. Relacionado con este problema de financiación, las circunstancias socio-económicas de los empleados de Erosmer Ibérica son idénticas a las del perfil de la clase media, por lo tanto, su capacidad de ahorro es limitada (ya que su poder adquisitivo también lo es) e insuficiente para poder afrontar, en el ámbito accionarial, la extrema competencia que supondría la presencia de inversores tan sumamente potentes como los integrados por EROSMER, es decir, CECOSA, ARGENTARIA, LAGUN ARO, G.D.E, BBK u ONCE, en la Asamblea General de accionistas de Erosmer Ibérica. En conclusión, la minoritaria parte del capital social de Erosmer Ibérica en manos de Gespa, le impide a ésta (como accionista) ejercer un control sufientemente eficaz sobre la citada sociedad anónima.

Pero, como anteriormente hemos señalado, el poder de decisión ejercido por Gespa sobre Erosmer Ibérica es superior al concedido por la mera participación económica que la sociedad civil particular posee en el accionariado de la sociedad capitalista: los estatutos de Gespa y el reconocimiento en documento público efectuado por Cecosa así lo 
permiten. De este modo, el Consejo Rector de Gespa acuerda el despido laboral de los trabajadores de Erosmer Ibérica que al mismo tiempo sean socios suyos, y opina y da orientaciones sobre el nombramiento de los directivos y gerentes de las diferentes empresas. A nuestro parecer, esta potestad constituye un gran paso adelante hacia mayores cuotas de participación de los trabajadores.

Por otro lado, si bien los requisitos para ser admitido como socio de GESPA, o por el contrario, para causar baja o cese, son explícitamente señalados y fijados para los socios de clase A, CECOSA no está obligada a cumplir condición alguna para su permanencia en la sociedad particular: su único deber es aportar al capital social de GESPA su parte correspondiente, es decir, el $50 \%$ del mismo, ya que el capital social está formado de forma paritaria entre las dos entidades.

Analizando la estructura societaria y composición de los diferentes órganos de la sociedad civil particular, en todos ellos CECOSA (socio de clase B) ostenta el $50 \%$ de los miembros componentes. Queda patente en todo momento el control ejercido en el seno de Gespa por parte de CECOSA: a pesar de poseer una participación paritaria en todos los aspectos (Asamblea General, Consejo Rector y Capital Social), no debemos olvidar que Gespa gestiona las participaciones invertidas en Erosmer Ibérica, donde el accionariado mayoritario se encuentra en manos de la sociedad anónima Erosmer. Como ya hemos señalado, esta participación minoritaria de Gespa se vería aumentada por sus competencias en materia laboral y de gestión, ejercidas sobre Erosmer Ibérica: no obstante, CECOSA (representante de las dos cooperativas Eroski y Consum), es socio mayoritario en todas las sociedades miembros del GRUPO EROSKI, es decir, posee el control mayoritario sobre EROSMER, S.A. y por lo tanto, también sobre EROSMER IBERICA, ya que la primera invierte totalmente su capital en la segunda. Si a este hecho sumamos el poder social ejercido por CECOSA dentro de la vida societaria de GESPA, la sociedad instrumental utilizada por EROSKI, S.Coop y CONSUM, S.Coop ostenta claramente la soberanía sobre todas las sociedades del Grupo.

A pesar de las potestades en matería laboral que posee Gespa, CECOSA nunca permitiría un enfrentamiento entre los intereses de los trabajadores y los suyos (reflejados tanto en las necesidades de EROSMER, como en las de EROSMER IBERICA), es decir, Gespa en ningún momento actuará como una entidad estrictamente independiente de Erosmer lbérica, por lo menos, en lo que a la defensa de los derechos 
de sus trabajadores se refiere. Encontramos un atenuado Conflicto de Intereses entre los trabajadores de Erosmer Ibérica y Cecosa. Por ejemplo, el caso de un trabajador en proceso de despido laboral: Gespa debe acordar la validez de dicho despido, y efectivamente lo hará, si el Consejo Rector, integrado en un $50 \%$ por CECOSA, así lo determina. De aunarse los intereses de CECOSA y EROSMER IBERICA en la citada situación, los socios de clase A no tendrán margen de acción alguno a la hora de decidir la continuidad del trabajador.

Ciertamente, el papel desempeñado por CECOSA dentro de GESPA se nos muestra, por lo menos, difuso: controlar la sociedad particular y, a través de ella, ceder una ínfima parcela de poder a los trabajadores, manteniendo intacta la soberanía ejercida por parte de Eroski S.Coop y Consum S.Coop sobre Erosmer Ibérica. El objeto último de Gespa es fomentar la participación de los trabajadores en la sociedad anónima donde desarrollan su labor: creemos que así es, pero se trata de una participación tremendamente controlada que, en ningún momento, aceptaría una contraposición de intereses entre propietarios y trabajadores (en una pequeña medida, también propietarios).

Otro punto relativo a la eficacia del efecto "cooperativizador» de Gespa, es la problemática del acceso al mercado de capitales de las sociedades de capitales "cooperativizadas»: en el caso de que Gespa constituyese realmente un mecanismo de participación efectivo en el seno de Erosmer Ibérica, esta última encontraría las mismas dificultades de financiación sufridas tanto por las sociedades cooperativas, como por las sociedades laborales. Estos tipos de entidades maximizan las retribuciones de trabajo a costa de los resultados obtenidos en el ejercicio, minimizando la retribución al capital y produciendo una natural desconfianza en el inversor ${ }^{53}$. Neutralizar dicha desconfianza es la causa de creación del modelo de expansión no-cooperativo de Eroski, destinado a captar financiación externa, precisamente, a través de la potenciación de la credibilidad ante los inversores. "Cooperativizar» en un alto grado EROSMER IBERICA, trastocaría la validez del medio empleado (el modelo de expansión) y la finalidad del proceso (acceder al mercado de capitales).

Garantizando el porcentaje máximo de participación laboral en el accionariado, acorde con el fin último del modelo de expansión (captación de capital), este modelo atenuado de «Cooperativización» de

53 Zelala UlíBARRI, Adrián, (1995), op. cit., páginas 91-92. 
la sociedad capitalista es perfectamente clasificable como un mecanismo de «Cuasigestión»: el límite máximo de participación societaria por parte de los trabajadores será aquel que permita a los capitalistas ejercer el control real de la sociedad, por lo tanto, nunca conformará un porcentaje superior al $50 \%$ del capital (según las diferentes normativas de derecho societario comparado, entre un $10 \%$ y un tercio del capital social). La finalidad de este modelo participativo es interesar a los trabajadores en la marcha de la sociedad, incentivando de tal manera un aumento de la productividad empresarial ${ }^{54}$. Citando las palabras de Imanol Torres, presidente del Consejo Rector de Gespa, «uno de los cambios que se están produciendo en la actualidad, hace mención a considerar el capital humano de las empresas como la única ventaja competitiva sostenible. Y esta ventaja competitiva sólo se consigue comprometiendo a las personas en la marcha de las empresas, buscando, en definitiva, una mayor participación». En este sentido, la finalidad de Gespa concuerda con las líneas de actuación destinadas a incrementar la eficacia empresarial.

Otra consecuencia, o tal vez finalidad por la que se han constituido en incontables ocasiones este tipo de instrumento "cooperativizador», es el desplazamiento de las fuerzas sindicales ${ }^{55}$ : la participación del trabajador en la empresa promueve una identificación entre el empleado y los fines de la entidad donde desarrolla su labor, creándose un clima laboral donde las revindicaciones sindicales carecen, cada vez en mayor medida, de sentido alguno. Tal y como establece el artículo 10 de los estatutos sociales de Gespa, «El socio está obligado a contribuir a un adecuado clima social y a una respetuosa convivencia con los directivos como con los demás socios». No obstante, y a pesar de la posible coincidencia del modelo de gestión de participaciones Gespa con el efecto anti-sindical antes descrito, dentro de la estructura societaria de dicho mecanismo, sí existe lugar para la representación sindical: el presidente del Comité de Empresa es miembro permanente del Consejo Social.

Como conclusión, señalamos que, a pesar del notable control efectuado por CECOSA sobre la actividad de Gespa y el conflicto de intereses que esto supone, y a pesar del carácter minoritario de la masa accionarial de Gespa en la sociedad anónima, este proyecto dé-

54 DIVAR, Javier (1983), op. cit., página 52.

55 KISMAR, Sharryn (1996), "The Myth of Mondragon». Cooperatives, Politics, and Working-Class Life in a Basque Town, New York. 
bilmente "cooperativizador» debería ser un paso más en el camino hacia una mayor participación de los trabajadores en la empresa. Tal y como afirma J. Divar 56 , «la participación mediante la reconversión del trabajador en accionista supone su consideración real como partícipe, dándole a la empresa un carácter de utilidad comunitaria». No obstante, este paso, hoy por hoy, es difuso e insuficiente y por tanto, el intento de "exportar» el espíritu cooperativo a la sociedad anónima EROSMER IBERICA también.

3.4. Adecuación del modelo de expansión de Eroski S. Coop a los Valores de la cultura económica del cooperativismo

Como ya hemos adelantado, dicho modelo de crecimiento tiene como objetivo último, lograr una adecuada dimensión empresarial sin poner en peligro la esencia cooperativa de las empresas originarias, es decir, preservando el «núcleo cooperativo» de las injerencias externas (materializadas en los instrumentos financieros de carácter societario). No obstante, la creación de sociedades de capitales, aun siendo participadas mayoritariamente por empresas cooperativas, vulnera en esencia la identidad cooperativa. Este proceso "Desnaturalizador» se vería atenuado si el mecanismo "cooperativizador» Gespa constituyese, en verdad, una garantía de participación y democracia para los trabajadores. En nuestra opinión, se trata de un elemento un tanto difuso y no es, de ninguna manera, definitivo a la hora de ampliar las bases sociales de la empresa. Por lo tanto, la elección de un modelo de expansión realizado íntegramente a través de sociedades de capitales, «desnaturaliza» ampliamente la entidad cooperativa en lo que a su área externa se refiere, ya que la interna se mantiene fiel a las normas de funcionamiento de origen rochdaleano.

En esencia, se trata de un proyecto insolidario con los trabajadores de Erosmer Ibérica, ya que, a pesar del intento "cooperativizador» realizado mediante GESPA, en absoluto poseen las atribuciones democráticas propias de los cooperativistas de Eroski, S.Coop y Consum, S.Coop: desarrollan su actividad laboral en una empresa capitalista, por lo tanto carecen del derecho democrático a participar en la vida socio-económica de la empresa, tanto en el ámbito societario (y sobre todo en el ámbito societario, mediante el principio de «una persona, un voto»), como en el área relativa a la gestión puramente empresa-

56 Divar, Javier (1990), «La Democracia Económica», Universidad de Deusto, Bilbao, página 56. 
rial; carecen, además, de una participación económica en los resultados del ejercicio, una participación no relacionada directamente con el capital aportado, sino con la actividad laboral realmente efectuada.

Este tipo de insolidaridad con la dignidad de los trabajadores únicamente se produce en el área exterior o general de la cooperativa, es decir, en su proyección externa no-cooperativa. Con respecto a la Declaración de la Identidad Cooperativa promulgada por la $\mathrm{ACl}$, el modelo de expansión realizado mediante sociedades anónimas daña de manera evidente el Valor de Solidaridad. Si bien el sistema cooperativo de organización empresarial promueve la plena participación de las personas en el sistema productivo, humanizándolo progresivamente, la sociedad capitalista enajena al trabajador y atenta contra su dignidad, privándole de los derechos democráticos más relevantes en el ámbito económico, es decir, los establecidos por la Democracia Económica. Al no garantizar la observancia de las reglas éticas en el entorno empresarial «no-cooperativo», el tratamiento sufrido por los trabajadores por cuenta ajena es favorecedor de la desigualdad con respecto a los cooperativistas del Grupo Eroski (quebrantamiento del Valor lgualdad), ya que los dos tipos de trabajadores desarrollan la misma actividad con desigual retribución dineraria y moral (quebrantamiento Valor Equidad). Por lo tanto, la Vocación Social a la que deberiera tender toda sociedad cooperativa es anulada en gran medida en este proceso, ya que, como hemos señalado, se trata de un proceso esencialmente falto de solidaridad; tal y como afirma J. Divar ${ }^{57}$, esta solidaridad interesada implica «no abusar del prójimo, porque al que se explota puede ser uno mismo». Esta solidaridad no la tiene el capitalismo.

Por lo tanto, el Sexto Principio de la $\mathrm{ACl}$, Cooperación entre Cooperativas, se nos aparece desdibujado, ya que, si su fin último es impulsar el movimiento cooperativo, ciertamente no lo consigue, lo desvirtúa.

En relación a los valores de la Experiencia de Mondragón, percibimos una atenuación de su filosofía, materializada en la lesión de varios de sus principios y valores fundamentales con proyección exterior (ya que el «núcleo cooperativo» se encuentra intacto): por un lado, con su Carácter Universal, la experiencia y las empresas que la integran (entre ellas, Eroski), "proclama su solidaridad con todos los que colaboran por la Democracia Económica en el ámbito de la Economía

57 DIVAR, Javier (1983), op. cit., páginas 86-87. 
Social, haciendo suyos los objetivos de Paz, Justicia y Desarrollo, propios del Cooperativismo»; por otro lado, el valor relativo a la Responsabilidad Social, es decir, "la distribución solidaria de la riqueza y la implicación en el entorno» implica impulsar el acceso de las personas de las empresas del área de influencia de MCC a condiciones socio-laborales equivalentes a las de los socios cooperativistas. Es evidente, que en el obligado proceso de expansión de Eroski, se ha colaborado de manera muy somera al desarrollo de la Democracia Económica, y en consecuencia, ha sido imposible trasladar a los trabajadores por cuenta ajena los elementos de la gestión y participación propios del ámbito cooperativo.

No obstante, y a pesar de mostrarnos críticos ante la «desnaturalización» de la esencia cooperativa en el modelo de expansión de Eroski, debemos recalcar lo necesario y obligatorio de este proceso: si bien no constituye un impulso claro al movimiento cooperativo, sirve para mantenerlo intacto y viable dentro de un mercado rigurosamente competitivo. En definitiva, nos guste o no, es una forma de preservar el funcionamiento cooperativo de ciertas empresas, que de no ser así, se verían abocadas a la financiación externa mediante instrumentos jurídicos de carácter societario, o bien a realizar su conversión en cooperativas mixtas 0 , en última instancia, en sociedades de capitales, malogrando totalmente su naturaleza rochdaleana.

En conclusión, apostemos para que el proceso «cooperativizador» de Erosmer Ibérica logre tal desarrollo que, llegado momento, la totalidad de la estructura societaria del Grupo Eroski sea, finalmente, cooperativa.

\section{La «Desnaturalización» de las Cooperativas: capitalismo y re- formismo cooperativo. Conclusiones generales}

A lo largo del presente trabajo hemos abogado por una postura heterodoxa, señalado con rotundidad la necesidad imperante de financiación sufrida por las empresas cooperativas, descrito detalladamente el entorno competitivo y concurrencial que constituye el mercado libre, y asegurado, sin lugar a dudas, la estrecha relación entre el capitalismo y el cooperativismo.

No obstante, paralelamente se ha tratado de desarrollar una profunda crítica con respecto a la pérdida de los valores cooperativos clásicos de origen rochdaleano, censores de toda participación meramente capitalista en el seno de la sociedad cooperativa. La 
contradicción aparente acaecida en la realidad, responde al carácter reformista del propio cooperativismo, ya que, sin aceptar los postulados capitalistas, convive y compite con ellos.

Por lo tanto, el movimiento cooperativo se nos muestra como una «contestación reposada, realista y altamente eficaz» contra los abusos del sistema capitalista: ésta es la esencia de la postura reformista, su realismo. Tal y como afirmó Arizmendiarrieta ${ }^{58}$, "hemos renunciado al sistema capitalista, pero no a la necesidad de disponer cada vez de más amplios capitales»: la financiación es imprescindible para adquirir una adecuada dimensión empresarial (necesaria, a su vez, para competir y sobrevivir en un mercado concurrencial), por lo que su captación (ante la imposibilidad de autogenerar los recursos suficientes) constituye un reto del cooperativismo actual. Los instrumentos compatibles y congruentes con la consecución de dicho fin son variados, si bien en el presente trabajo únicamente hemos desarrollado los potencialmente "desnaturalizadores»: algunos de ellos, permiten la concesión de derechos societarios a los aportantes de capital; otros permiten la captación de capital y la expansión empresarial a través de un modo ajeno al cooperativo. Y todo ello, con el propósito de evitar una posible «Desmutualización» (transformación de la sociedad cooperativa en una empresa capitalista) o liquidación de la cooperativa.

La necesidad práctica y el temor a una posible «muerte» económica de la entidad cooperativa, nos obliga, muy a nuestro pesar, a aceptar en cierto grado la «desnaturalización» de algunas cooperativas, en concreto, las que efectivamente cohabitan en el mercado libre bajo una gran amenaza competetitiva.

Esta desvirtuación del modelo cooperativo clásico es el fundamento de muchos críticos del cooperativismo, que señalan tajantes el alto grado de consonancia e integración en el sistema capitalista del cooperativismo en general, y de las cooperativas «desnaturalizadas», en particular. Si nuestra réplica como admiradores del movimiento cooperativo y de sus logros tanto económicos como sobre todo sociales, es en esencia pragmática, añadiremos que éste es «el difícil camino del cambio no violento».

58 ArizMendiarretA, Jose María (1983), op. cit., pág 193. 


\section{Bibliografía}

1. Alonso, Eva (1999), «Algunos comentarios sobre la nueva Ley $27 / 99$, de Cooperativas», Anuario de Estudios Cooperativos, Universidad de Deusto, Bilbao.

2. Arizmendiarrieta, Jose María, Pensamientos, Mondragón.

3. Böök, S.A. "Valores cooperativos para un mundo cambiante», Informe para el XXX Congreso de la ACl, Tokio, octubre de 1992.

4. CÁCERES, Javier (1988), "Globalización: la Reestructuración de la Industria del Trigo Canadiense», Revista de la Cooperación Internacional, Argentina, n. ${ }^{\circ} 31$.

5. Cracogna, Dante (1993), «La Identidad Cooperativa en un mundo cambiante», Anuario de Estudios Cooperativos, Universidad de Deusto, Bilbao.

6. Dacosta, Constan (1991), «Eroski, una adaptación al cambio», Anuario de Estudios Cooperativos, Universidad de Deusto, Bilbao.

7. Divar, Javier (1983), La Metamorfosis del capital. Bases de la empresa futura, Universidad de Deusto, Bilbao.

8. Divar, Javier (1990), La Democracia económica, Universidad de Deusto, Bilbao.

9. DIVAR, Javier, «Los valores cooperativos ante el reto de la globalización», Simposio sobre los Valores de la Cultura económica del Cooperativismo Vasco», Universidad de Deusto, Bilbao, 28 de noviembre de 2001.

10. Empresas AvanzAdAS en Gestión, "Grupo Eroski. El crecimiento con calidad como filosofía de actuación».

11. Federación de Cooperativas de Euskadi (1994), Historia de las Cooperativas de Consumo Vascas, Vitoria-Gasteiz.

12. Gadea, Enrique (1999), Derecho de las Cooperativas. Análisis de la Ley 4/1993, de junio, de Cooperativas del País Vasco», Universidad de Deusto, Bilbao.

13. GADEA, Enrique. "Tendencias Legislativas Internacionales», módulo integrado en el Curso de Especialización en Estudios Cooperativos, Universidad de Deusto, Bilbao, 29 de noviembre de 2001.

14. García Gutíerrez, Carlos. «La Rentabilidad Económico-Financiera de los socios», I Jornadas Universitarias de Economía Social, Facultad de Ciencias Económicas y Empresariales de la UPV/EHU (Sarriko), Bilbao, 11, 12 y 13 de marzo de 2002. Inédito.

15. Gómez Urquijo, Laura, "Caso de Cooperativas Excelentes, Eroski», módulo integrado en el Curso de Especialización en Estudios Cooperativos, Universidad de Deusto, año 2002.

16. Gómez Urquijo, Laura y De los Ríos AÑón, Marta (1997), «Respuestas a las dificultades de captación de capital en las Cooperativas: El Caso Eroski», Anuario de Estudios Cooperativos, Universidad de Deusto, Bilbao.

17. Cooperativa de Consumo Eroski (1994), 25 años de consumerismo, Elorrio.

18. Gorroño, Iñaki (1975), Experiencia cooperativa en el País Vasco, Durango. 
19. LANKI, Lankidetzaren Ikertegia (1999), «Lankidetza. Arizmendiarrietaren eraldaketa proiektua», Lanki ikertegia, Mondragón Unibertsitatea, Arrasate-Mondragón .

20. Kaplan De Drimer, Alicia (1995), «El XXXI Congreso de la Alianza Cooperativa Internacional y la Nueva Formulación de los Principios Cooperativos», Anuario de Estudios Cooperativos, Universidad de Deusto, Bilbao.

21. Kaplan De Drimer, Alicia (1998), «¿Dejaríamos entrar a los zorros en los gallineros?», Anuario de Estudios Cooperativos, Universidad de Deusto, Bilbao.

22. Kaplan De Drimer, Alicia (1998), «Enemigos Invisibles: El Caso de C.W.S. de Gran Bretaña», Anuario de Estudios Cooperativos, Universidad de Deusto, Bilbao.

23. Kaplan De Drimer, Alicia (1999), «El Rol del Cooperativismo en el próximo milenio», Anuario de Estudios Cooperativos, Universidad de Deusto, Bilbao.

24. Kaplan De Drimer, Alicia (2000), "Las cooperativas ante los peligros de «Desnaturalización» y «Desmutualización», Anuario de Estudios Cooperativos, Universidad de Deusto, Bilbao.

25. KASMIR, Sharryn (1996), The Mith of Mondragón. Politics, and WorkingClass Life in a Basque Town, New York.

26. MCPHeRson, I. «Reformulación de los Principios Cooperativos». Noticias. Asociación Latinoamericana de Centros de Educación Cooperativa (ALCE(OOP), Argentina.

27. OlabarRía, Ignacio (1984), «Tradiciones cooperativas vascas», Euskal Herria, Historia y Sociedad, Ed. Caja Laboral.

28. SalaberRía Amesti, Javier (1995), El Régimen Económico-Financiero de las Cooperativas de Trabajo Asociado, Federación de Cooperativas de Trabajo Asociado de Euskadi, páginas 78-79, Vitoria-Gasteiz.

29. SalaberRía Amesti, Javier, "Los Valores del Movimiento Cooperativo Vasco», Simposio sobre los valores de la cultura económica del cooperativismo vasco, Universidad de Deusto, 28 de noviembre de 2001. Inédito.

30. Salaberría Amesti, Javier, "Las Cooperativas Vascas: Presente y Futuro», I Jornadas Universitarias de Economía Social, Facultad de Ciencias Económicas y Empresariales de la UPV/EHU, Sarriko, Bilbao, 11 de marzo de 2002. Inédito.

31. Rosembuj ERUJiMOVICH, Tulio, «Los valores de la cultura económica del cooperativismo», Simposio sobre los valores de la cultura económica del cooperativismo vasco, Universidad de Deusto, Bilbao, 28 de noviembre de 2001.

32. Ugarte AzPIRI, Luis Mari (2000), «Mondragón Corporación Cooperativa, historia de una experiencia», Revista de Estudios de Juventud: "Cooperativas, Sociedades Laborales, Juventud y autoempleo», n. ${ }^{\circ}$ 51, Injuve, Madrid.

33. Zelala UlíbarRI, Adrián (1992), «Estructura y problemática jurídica de la Corporación MCC», en Anuario de Estudios Cooperativos, Universidad de Deusto, Bilbao.

34. Zelala Ulíbarrl, Adrián (1992), Capital y Sociedad Cooperativa, Madrid. 
35. Zelala UlíbarRI, Adrián (1997), «Valores del Cooperativismo Vasco en Arizmendiarrieta», Anuario de Estudios Cooperativos, Universidad de Deusto, Bilbao.

36. Zelala Ulíbarri, Adrián (1995), Acceso de las Cooperativas al Mercado de Capitales, Mondragón.

37. ZelAIA UlíBARRI, Adrián (1997), Kooperatibak Euskal Herrian, Udako Euskal Unibertsitatea, Bilbo.

38. Zelala UlíbarRI, Adrián, «La experiencia del Grupo Mondragón», Simposio sobre los Valores de la Cultura Económica del Cooperativismo Vasco, Universidad de Deusto, Bilbao, 28 de Noviembre de 2001. 